\title{
INDEPENDENCIA O CONSTITUCIÓN: AMÉRICA EN EL TRIENIO LIBERAL*
}

\section{INDEPENDENCE OR CONSTITUTION: SPANISH AMERICA IN THE LIBERAL TRIENNIUM}

\author{
Ivana Frasquet \\ Universitat de València
}

\begin{abstract}
SUMARIO: I. INTRODUCCIÓN.- II. LA REFORMA CONSTITUCIONAL.- 2.1. La revisión constitucional en el Trienio.- III. LA CUESTIÓN AMERICANA Y LA CONSTITUCIÓN DE CÁDIZ.- 3.1. Un plan de monarquías para América.- 3.2. La inconstitucionalidad del proyecto federal. 3.3.- El "inevitable" final. IV.- EPÍLOGO: ¿IMPIDIÓ LA CONSTITUCIÓN DE 1812 UNA SOLUCIÓN PARA AMÉRICA?
\end{abstract}

Resumen: El Trienio Liberal fue la segunda oportunidad para establecer una monarquía constitucional en España y en los territorios americanos. Los diputados de América que participaron en los debates parlamentarios plantearon, una vez más, las propuestas de autogobierno y autonomía que el sistema constitucional les permitía. En este sentido, pusieron sus esperanzas en la Constitución de 1812 que, si bien era inclusiva, su rigidez impedía la modificación de la estructura jurídica y territorial del imperio. En este trabajo, pretendemos acercarnos a las propuestas y debates políticos que sobre la posible modificación de la Constitución se tuvieron en las Cortes del Trienio Liberal (1820-1823) para comprender por qué en el marco del liberalismo de los años veinte, no fue posible mantener la monarquía unida y la presencia del texto constitucional acabó siendo un impedimento para el autogobierno americano y una causa más para abrazar la independencia.

\begin{abstract}
The Liberal Triennium was the second opportunity to establish a constitutional monarchy in Spain and the American territories. The deputies of America who participated in the parliamentary debates raised, once again, the proposals for self-government and autonomy that the constitutional system allowed them. In this sense, they put their hopes in the Constitution of 1812 that, although it was inclusive, its rigidity prevented the modification of the legal and territorial structure of the empire. In this work, I intend to approach the proposals and political debates that on the possible modification of the Constitution were held in the Liberal Triennium Courts (1820-1823) to understand why in the framework of the liberalism of the twenties, it was not possible keeping the monarchy together and the presence of the constitutional text ended up being an impediment to American self-government and another cause for embracing independence.
\end{abstract}

Palabras clave: Constitución de 1812, Fernando VII, Diputados americanos, Reforma constitucional, Rigidez 
Key words: Constitution of 1812, Ferdinand VII, American deputies, Constitutional reform, Rigidity

Comprendo una guerra de conquista, comprendo una guerra de sucesión, una guerra para el cambio o la conservación de una dinastía particular; pero una guerra para la modificación de una constitución politica, una guerra por dos cámaras y por la extensión de la prerrogativa real, una guerra por semejantes objetivos, realmente no la comprendo.

George Canning ${ }^{1}$

\section{INTRODUCCIÓN}

Cuando en enero de 1823 el líder de la diplomacia británica escribía estas palabras a su homólogo francés, la suerte del constitucionalismo español parecía ya echada. La guerra, auspiciada por Francia, era por entonces prácticamente inevitable en tanto que las potencias santoaliadas -Austria, Rusia y Prusiahabian declarado formalmente que jamás reconocerian un gobierno fundado en una rebelión. Las notas de los gabinetes europeos, condenando el origen del sistema político español implantado desde 1820 , se habian presentado a las Cortes el 9 del mismo mes ${ }^{2}$. La lectura de estos informes diplomáticos causó gran escándalo en el Congreso, los diputados que asistieron a la sesión rechazaron unánimemente la injerencia de los gobiernos extranjeros en los asuntos de la nación y defendieron firmemente las instituciones constitucionales. El liberalismo español se veía sorprendido por los peligros inminentes que amenazaban su continuidad, a pesar de las pruebas que el legitimismo monárquico europeo ya había dado de perseguir y atentar contra todos los regímenes asentados sobre las bases del constitucionalismo gaditano. Muestra de ello había sido la intervención militar en Nápoles aprobada en el congreso de Laybach a finales de 1820.

Ese dia de enero de 1823, las Cortes cerraron filas de manera uniforme en torno al gobierno y la Constitución. No era momento de desavenencias internas para el liberalismo. Agustín Argüelles, desde el doceañismo, tendía la mano a uno de los líderes exaltados, Antonio Alcalá Galiano, para responder a la afrenta extranjera: "Si alguna vez hemos disentido en opiniones, he dicho desde el primer

* Esta investigación forma parte del proyecto financiado por MINECO con referencia HAR201678769-P.

1 Carta del Sr. Canning al Sr. de Chateaubriand. Londres, 21 de enero de 1823. Reproducida en François René de Chateaubriand, Congreso de Verona. Guerra de España. Negociaciones. Colonias Españolas, Papeles del Tiempo n 22. Machado Libros, Madrid, 2011, p. 245.

2 La nota del Consejo de ministros francés indicaba: "Una insurrección militar sujetó al rey Fernando a una Constitución que no había reconocido ni aceptado al volver a subir al Trono" (p. 1293). La de Prusia consideraba: "Una revolución nacida de un motín militar ha roto repentinamente todos los lazos del deber, trastornando todo orden legitimo" (p. 1295). La de Rusia afirmaba: "en el mes de marzo de 1820 algunos solados perjuros volvieron sus armas contra su soberano y su patria para imponer a la España unas leyes que la razón pública de Europa [...] desaprobaba altamente" (p. 1296). La de Austria apostillaba: "la rebelión militar nunca puede formar la base de un gobierno feliz y duradero" (p. 1297). Diario de Sesiones de Cortes, 9 de enero de 1823. (En adelante DSC) 
día que la base era común a todos nosotros: a saber, la Constitución del año 1812"3. Y así parecía ser, pues los taquígrafos no dejaron de transcribir las expresiones encendidas de apoyo de los diputados y el sentir unánime de rechazo a las notas europeas ${ }^{4}$.

Durante los tres años transcurridos entre 1820 y 1823, el sistema de gobierno encarnado y materializado en la Constitución de 1812 se situó en el centro del debate político. Esta se había convertido en el objetivo medular de todas las posiciones politicas que existieron en el mundo euroamericano. De un extremo a otro del arco ideológico que iba del liberalismo exaltado al absolutismo reaccionario, el texto aprobado en Cádiz a inicios de la década anterior, acabó protagonizando las más agrias polémicas, las más frustradas esperanzas, los deseos más insondables y los peores temores, tanto de quienes lo defendian como de quienes lo detestaban.

Y es que, al parecer, la sola existencia de la Constitución española alteraba los ánimos del moderado y liberal gobierno británico, del doctrinarismo francés de carta otorgada y, por supuesto, de las cortes absolutistas europeas. Ya en mayo de 1820, el ministro de asuntos exteriores británico habia advertido de los peligros de restaurar una Constitución de "naturaleza republicana" y de la necesidad perentoria de reformarla para adaptarla a los principios del liberalismo moderado $^{5}$. Y en ello residiría finalmente el pretexto para la intervención militar en España, en la exigencia francesa de reformar la Constitución española para otorgarle al rey los derechos que, supuestamente, le habían sido usurpados por el liberalismo democrático y de tendencia anárquica. Por ello, en respuesta a la misiva británica que encabeza estas páginas, el ministro de asuntos exteriores francés, Chateaubriand, coincidia en la conveniencia de que la Constitución

\footnotetext{
3 DSC, 9 de enero de 1823, p. 1300. Años más tarde, en 1834, Argüelles, en su Apéndice a la sentencia de la Audiencia de Sevilla, publicado en Londres, expresaria con cierta nostalgia la convicción de que el liberalismo español no se hallaba dividido en aquella memorable sesión del mes de enero: "no fue, no, idolatría a la constitución que regía entonces; no lo fue a una u otra teoria de gobierno representativo, ni tampoco a doctrinas o nociones especulativas de esta clase, sino un convencimiento intimo, profundo, irresistible en el ánimo de los diputados, sin relación a opiniones o principios políticos; convencimiento que les puso delante de los ojos cuál iba a ser la suerte futura de la nación despojada de su independencia y sus derechos, entregada al influjo extranjero y condenada nuevamente a la humillación y vilipendio en que cayó después de 1814". De 1820 a 1824. Reseña Histórica por D. Agustín Argüelles, Cito la edición publicada en Madrid en 1864 con noticia biográfica del autor por José de Olózaga y prólogo de Ángel Fernández de los Ríos. La cita en las páginas 121-122.

4 Estas transcripciones permiten hacerse una idea del clima de crispación y a la vez de solidaridad, que reinó aquel día en el salón de sesiones: "Varios Sres. Diputados exclamaron: A todos, a todos han sido dirigidas; a toda la Nación"; "Se repitieron los mismos aplausos y aclamaciones con vehemencia"; "Aplausos repetidos de los Sres. Diputados y espectadores"; "Muchos Sres. Diputados: Ya no hay más disentimientos entre nosotros". DSC, 9 de enero de 1823, pp. 1299-1301. El propio Alcalá Galiano, años más tarde, describiría en sus memorias el "espectáculo tierno y sublime" de aquel día: ... "arrojándose a los brazos unos de otros los diputados, y más particularmente los hasta entonces más opuestos en opiniones, y señalándose entre todos Argüelles y yo, que nos abrazamos estrechamente, derramando copiosas lágrimas"... Memorias de D. Antonio Alcalá Galiano, publicadas por su hijo, edición digital a partir de Obras escogidas. Recuerdos y Memorias, t. I, Atlas, Madrid, 1955, p. 433.

5 Castlereagh afirmaba: "Todos podemos estar de acuerdo en que nada puede ser más diferente a un gobierno monárquico, o menos adecuado para las necesidades y los verdaderos intereses de la nación española, que la Constitución del año 1812". Memorandum, mayo 1820. National Archives. Foreign Office. Exp. 72/241, ff. 199-248v ${ }^{\mathrm{a}}$.
} 
española debía sufrir modificaciones, pero disentía en la manera de conseguir ese objetivo, pues exigía que el rey tuviera parte en las mismas ${ }^{6}$.

Por esta razón, las Cortes al escuchar la lectura de los informes de los gobiernos europeos, manifestaron su rechazo a una reforma constitucional impuesta bajo la coacción y la amenaza de una invasión inminente: "Fieles a su juramento, y dignas del pueblo a quien representan, no permitirán que se altere ni modifique la Constitución por la cual existen, sino por la voluntad de la nación y por los términos que la misma prescribe"7.

Sin embargo, no seria la primera vez que las Cortes debian defender la integridad del texto constitucional. La presencia de diputados americanos en la cámara en esta etapa volverá a poner sobre la mesa la problemática de una monarquía española constitucional de dimensiones territoriales transoceánicas. Fueron los americanos los que plantearon sin ambages la disyuntiva de mantenerse fieles a un diseño de Estado que constreñía sus deseos de autogobierno, por muy constitucional que este fuese, o lanzarse al incierto camino de una independencia cuyo resultado político todavía estaba por verse.

La Constitución de 1812 les garantizaba la aplicación de los principios liberales, pero les mantenía, al mismo tiempo, reducidos a un segundo plano en tanto se extendiese la situación de guerra y revolución en los territorios americanos. Por otro lado, el escenario de tensión entre el absolutismo y el liberalismo que se desató a partir de 1820 en Europa, poco contribuiría a considerar que la cuestión americana era un aspecto fundamental para la supervivencia del régimen constitucional.

En este sentido, ¿por qué era tan problemático abordar la reforma del texto constitucional? ¿Qué hacía de la Constitución de 1812 la norma inamovible que todos invocarian para mantenerse incólumes en sus posiciones? Y, sobre todo, desde la perspectiva de los americanos ¿cuándo la Constitución se convirtió en un obstáculo para permanecer unidos a un modelo de Estado que también ansiaban para sus patrias?

En este artículo me acerco a la cuestión de la reforma constitucional durante los años del Trienio desde el punto de vista de los diputados americanos -en especial los novohispanos-, cuyas propuestas politicas afrontaron el papel que la Constitución de 1812 debía jugar respecto a sus territorios, en una coyuntura tan distinta como lo sería la de esos años respecto a la década anterior. Los americanos interpretaron laxamente los preceptos constitucionales en materia territorial para hacerlos encajar en su pretensión federal. Para ellos, solo una lectura adaptada de la estructura de Estado contenida en el texto constitucional les permitiría continuar integrados en la monarquía. Sin embargo, como era de esperar, la negativa del liberalismo español a modificar la Constitución, si quiera a plantearse iniciar el procedimiento para ello, acabó por derrumbar la maltrecha unidad de la monarquía.

6 "Primeramente, ambos convenimos desde luego en que la Constitución española debe sufrir modificaciones; pero vos creéis que estas deben ser introducidas por el gobierno español”. Carta del Sr. de Chateaubriand al Sr. Canning. Londres, 27 de enero de 1823. Reproducida en François René de Chateaubriand, Congreso de Verona. Guerra de España. Negociaciones. Colonias Españolas, op. cit., p. 250.

7 DSC, 9 de enero de 1823, p. 1299. 


\section{LA REFORMA CONSTITUCIONAL}

Mucho se ha escrito sobre la cuestión esencial de la reforma constitucional y su papel como actividad normativa para modificar intencionadamente la Constitución. En este sentido, no voy sino a señalar sintéticamente los aspectos fundamentales de este asunto en relación a lo ya aportado al respecto sobre la Constitución de 1812, sin detenerme en las distintas interpretaciones a que ha dado lugar tan fructífero debate, por no ser el objeto de este trabajo.

La historiografia especializada ha resaltado asiduamente -siguiendo la división que en su día estableció James Bryce ${ }^{8}$ - la rigidez extrema del texto gaditano como una de sus características primordiales. Esta rigidez traeria origen en la manera en que se conformaron las Cortes extraordinarias de Cádiz en 1810 y la distinción, por tanto, que los liberales asentaron entre el poder constituyente $\mathrm{y}$ el poder constituido. Estos diputados liberales, que encarnaron el poder constituyente, diferenciaron oportunamente entre las Cortes constituyentes aquellas destinadas a elaborar una Constitución, considerando a esta como ley fundamental-y las ordinarias -aquellas que aprobaban leyes, decretos y órdenes. Además, también crearon las Cortes de revisión, que serian las destinadas a la reforma constitucional pero que también podian legislar de forma ordinaria, y que configurarian el llamado poder constituyente constituido9.

La regulación de la reforma constitucional quedó plasmada en el Título X de la Constitución dedicado a "La observancia de la Constitución y modo de proceder para hacer variaciones en ella", en los artículos del 372 al 384. En ellos se desplegaba un complejo procedimiento de modificación constitucional que tenía como finalidad proteger el texto de futuros cambios políticos que pretendieran acabar con él. El más llamativo de estos trámites era el que consideraba -en el artículo 375- que no podía ser reformada "hasta pasados ocho años después de hallarse puesta en práctica la Constitución en todas sus partes". Pero además, el resto del procedimiento era tan complejo y requería de tan complicados trámites que necesariamente la reforma se dilataría en el tiempo todavía más.

En primer lugar, la proposición de reforma debía presentarse por escrito avalada con la firma de veinte diputados. Seguidamente, esta debía pasar por

\footnotetext{
8 James Bryce, Constituciones flexibles y Constituciones rígidas, Centro de Estudios Politicos y Constitucionales, Madrid, [1884] 1988. Algunos autores han hablado incluso de "hiperrigidez" a la hora de calificar el texto gaditano. Véase Javier Tajadura Tejada, "La defensa de la Constitución en los orígenes del constitucionalismo hispánico: la "hiperrigidez" constitucional”, UNED. Revista de Derecho Politico, no 83, 2012, pp. 511-570.

9 La bibliografia al respecto es ya ingente, pero pueden consultarse específicamente los trabajos de Joaquín Varela Suanzes-Carpegna, Politica y Constitución en España (1808-1978), en especial el capítulo 10, La reforma constitucional en las Cortes de Cádiz y en la Constitución de 1812, Centro de estudios Políticos y Constitucionales, Madrid, 2014. Pedro de Vega, La reforma constitucional y la problemática del poder constituyente, Tecnos, Madrid, 1985. Santiago A. Roura Gómez, La defensa de la Constitución en la historia constitucional española, CEPC, Madrid, 1998. Javier Tajadura Tejada, "La problemática de los limites del poder de reforma constitucional en la Constitución de Cádiz. Límites materiales y limitación temporal”, Historia constitucional, $\mathrm{n}^{\circ} 13$, 2012, pp. 257-270. Noemí García Gestoso, "La reforma de la constitución de Cádiz. Algunas consideraciones a propósito de la defensa de la constitución”, Civitas Europa, n 29, 2012/2, pp. 53-77.
} 
tres lecturas en las Cortes antes de admitirla a discusión, siendo cada una de estas aprobada por una mayoría de dos tercios de los diputados presentes. Una vez cumplido este trámite, había que esperar a la siguiente legislatura para que se avalara en ella la propuesta de revisión y procediese a convocar unas terceras Cortes con poder reformador en las que, igualmente por mayoría cualificada de dos tercios, finalmente se podría sancionar la modificación del texto constitucional. De acuerdo con el procedimiento ideado por los constituyentes de 1812, el rey no tenía ningún protagonismo en la reforma de la Constitución, ni siquiera era necesario que la sancionara, se le relegaba a cumplir con el papel de hacer "publicar y circular a todas las autoridades y pueblos de la monarquia" el precepto constitucional como decreto de Cortes.

Como ha escrito Joaquín Varela, la rigidez constitucional procuraba que no fuera fácil reformar la Constitución para evitar prematuras modificaciones por parte de una débil mayoría parlamentaria antes de que se consolidara el nuevo orden liberal, así como para excluir conscientemente al monarca del proceso de reforma ${ }^{10}$. Igualmente, no se trataba únicamente de impedir que el monarca pudiera emprender la reforma del texto constitucional-que a la postre supusiera una involución en la transformación revolucionaria que el constitucionalismo gaditano representaba- sino de impedir que pudiera negarle su sanción a una reforma ya aprobada ${ }^{11}$. En el debate sobre este título que se sostuvo en las Cortes gaditanas, el diputado Díaz Caneja explicitaba la desconfianza que se tenia hacia los reyes porque "no estaban acostumbrados a vivir con Constitución", por eso era importante protegerla en los primeros años de su implantación.

Los liberales de Cádiz habían vinculado el principio de soberanía nacional a la protección del texto constitucional por la vía de la rigidez. Es decir, la modificación suponía un acto de soberanía ya que se trataba de variar lo que en su día había aprobado la voluntad general de la nación. Como ha indicado Santiago Roura, esta identificación entre el proceso constituyente y el de reforma -otorgando a ambos el principio de soberanía- suponía evidenciar que la nación, a través de sus representantes, era la única capacitada para darse y modificar la Constitución. Así, dificultar su cambio conllevaba preservar la decisión del poder constituyente $\mathrm{y}$, en cierta medida, asegurar la durabilidad del texto frente a posibles intervenciones del legislador ordinario. En el fondo no se trataba de negar por todos los medios la posibilidad de reformar la Constitución, aún cuando la voluntad de las constituciones modernas pudiera ser perpetuarse en el tiempo, sino de esperar a que se asentara el "sentimiento constitucional" antes de ser retocada. Es decir, el cambio debía asegurar la permanencia de la Constitución y evitar, por así decirlo, alteraciones del sistema político ${ }^{12}$.

Además, entre el articulado que delineaba el procedimiento de reforma no se diseñaron límites materiales o cláusulas de intangibilidad para la misma. Al decir

10 J. Varela Suanzes-Carpegna, Politica y Constitución en España, op. cit., p. 278. Véase también Ignacio Fernández Sarasola, La Constitución de Cádiz. Origen, contenido y proyección internacional, CEPC, Madrid, 2011, pp. 121-122.

11 S. A. Roura Gómez, La defensa de la Constitución en la historia constitucional española, op. cit., p. 155.

12 Javier Ruipérez, "Una cuestión nuclear para la teoría del derecho constitucional: sobre la reforma de la constitución y sus funciones en el estado constitucional democrático", Anuario da Facultade de Dereito da Universidade da Coruña, ${ }^{\circ}$ 1, 1997, pp. 455-498. 
de J. Varela, los diputados encauzaron la reforma por unos limites formales, lo que no impedía que toda institución regulada en la Constitución pudiera ser reformada o incluso suprimida. Esto suponía que la monarquía, a la que se le dedicaba el título IV, no podía situarse en un plano superior al del texto constitucional -ya que ello hubiera significado que se hallaba por encima de la voluntad de la nación- y era susceptible no sólo de revisión sino también de abolición ${ }^{13}$. Algo para lo que, por cierto, ya se habían intentado abrir cauces cuando se presentó el borrador del artículo $3^{\circ}$ en cuyo debate, finalmente, fue eliminada la frase que encaminaba esta cuestión. Recuérdese: "y de adoptar la forma de gobierno que más le convenga". De esta forma, la Constitución fue entendida como el origen y fundamento de todos los poderes (incluida la Corona) y no como la consagración de los ya existentes.

En su Discurso preliminar a la Constitución de 1812, Argüelles explicaba la reforma como un elemento de durabilidad del texto y como la ineludible necesidad de adaptarse al futuro: "Mas como no es dado a los hombres llegar a la perfección en ninguna de sus obras, como es inevitable que el influjo de las circunstancias tenga mucha parte en todas sus disposiciones, y aquellas pueden variar sensiblemente de una a otra época, es indispensable reconocer la dura necesidad de variar alguna vez lo que debiera ser inalterable"14.

El procedimiento de reforma se pensó así para evitar cambios inmediatos y esperar a que se consolidara el nuevo orden, pero también se preveía inevitable en el futuro para adaptar la Constitución al cambio histórico. La comisión constitucional era consciente de los riesgos que el texto corría una vez se conociera el sistema politico que establecia: "los resentimientos, las venganzas, las preocupaciones, los diversos intereses y hasta el hábito y la costumbre, todo, todo se conjurará contra ella". De esa manera, la reforma era necesaria para la estabilidad futura del sistema constitucional. Conservar y alterar la Constitución, aunque pareciera contradictorio, en realidad eran inseparables.

\subsection{La revisión constitucional en el Trienio}

No iban mal encaminados los liberales cuando advirtieron el peligro potencial que representaba el monarca para el sistema constitucional. Apenas llevaba en vigor dos años la Constitución cuando fue "borrada de en medio del tiempo" por un Fernando VII despótico y represor que se dedicó a ejercer el poder real de una forma sui generis e ilimitada. Al respecto, Emilio La Parra ha afirmado que no fue un rey absoluto como sus antepasados ni un monarca constitucional como deseaban los liberales, sino que "gobernó de otra forma, sin ajustarse exactamente a ningún precedente especifico"15.

13 En este sentido, la existencia de la monarquía no era un limite insuperable a la reforma constitucional. De esto se desprendía, según Varela, una idea puramente positiva y formal de la Constitución: "Era este (el texto constitucional) quien creaba y sentaba las bases de un orden jurídico-político y no el orden jurídico-político decantado por la historia el que creaba el orden constitucional, contraponiéndose y sobreponiéndose a él”. J. Varela Suanzes-Carpegna, Política y Constitución en España, op. cit., p. 283.

14 Agustín Argüelles, Discurso preliminar a la Constitución de 1812, Centro de estudios Politicos y Constitucionales, Madrid, 2011, p. 126.

15 Emilio La Parra, Fernando VII. Un rey deseado y detestado, Tusquets, Barcelona, 2018, p. 280 . 
De esta manera personal de gobernar, Fernando VII obtuvo el favor de las potencias europeas de la Santa Alianza que tanto le ayudarian a recuperar por segunda vez su trono absoluto en 1823. Es más, los seis años que transcurrieron entre 1814 y 1820 representaron la persecución y represión sin límites al liberalismo español en connivencia con unas monarquías legitimistas cuyo objetivo era imponer el orden moral a la sociedad y que se empeñaban en llamarse -como criticaría Argüelles- la "era de la restauración"16.

Los pronunciamientos liberales que jalonaron el sexenio absolutista fueron la prueba palpable de los síntomas de la convulsión politica que se avecinaba. Uno de ellos triunfó, y acabó obligando a Fernando VII a jurar la Constitución de 1812 y a restablecer el orden constitucional que seis años atrás había abolido. Las consecuencias de ello fueron inmediatas, se celebraron elecciones para reunir unas nuevas Cortes, se instalaron ayuntamientos constitucionales y diputaciones provinciales y los territorios americanos volvieron a ser considerados partes integrantes en calidad de igualdad de la monarquía.

Pero los seis años transcurridos no podían dejar indiferente a nadie. Algunas posiciones politicas se moderaron como las de los liberales que habian sufrido el exilio, aunque otras se radicalizaron, tanto hacia la democracia como hacia la reacción. Y ahí, según Argüelles, es cuando España se dividió en dos. Entre los que defendian el orden constitucional -con sus diferencias- y los que lo subvertian aprovechando la libertad que este les daba para provocar disensiones y alentar una guerra civil que justificara la intervención armada extranjera ${ }^{17}$.

En estas circunstancias parecia ineludible que la nueva puesta en planta del texto constitucional auspiciara el debate en torno a su posible reforma. Para algunos era evidente que tal y como estaba concebida, la Constitución ya no respondía, en 1820, a las necesidades de la España monárquica moderada que se deseaba establecer. Era imprescindible una segunda cámara que contuviera las veleidades revolucionarias de la asamblea legislativa. Para otros, la reforma debía ser profunda y restauradora de los derechos que los constituyentes gaditanos habian arrebatado al rey en la concepción del título IV, sobre todo en lo referente al veto y prerrogativas reales. Pero, como recordaba Argüelles, la posición habitual fue que la mayoria parlamentaria no quisiera ni oír hablar de iniciar un procedimiento de reforma constitucional:

[...] en general los liberales en 1820, evitaron por intempestiva la delicada disputa sobre reformar la Constitución antes de la época señalada; creyendo que mientras llegaba el plazo, la libre discusión y las lecciones prácticas de

16 Sobre la represión fernandina en la primera restauración todavía faltan estudios amplios, pero pueden consultarse los trabajos especificos siguientes: Ignacio Lasa Iraola, "El primer proceso a los liberales (1814-1815)", Hispania, no 115 (1970), pp. 327-383. Miguel Artola Gallego, "La represión política" en Santiago Muñoz Machado (ed.), Los grandes procesos de la historia de España, Justel, Madrid, 2010, pp. 441-450. Pedro Rújula López, "Isidoro de Antillón y la represión de los diputados liberales en 1814", Teruel, no 95-96, 2014-2015, pp. 251-265. Ivana Frasquet, "En defensa de la Constitución. Persecución y juicio a los diputados de las Cortes en tiempos contrarrevolucionarios, 1814-1815", en I. Frasquet y E. García Monerris, Tiempo de politica, tiempo de Constitución. La monarquía hispánica entre la revolución y la reacción (17801840), Comares, Granada, 2018, pp. 213-238. Y los textos recogidos en el volumen colectivo Marieta Cantos Casenave y Alberto Ramos Santana (eds.), La represión absolutista y el exilio, Universidad de Cádiz, Cádiz, 2015.

17 De 1820 a 1824. Reseña Histórica por D. Agustín Argüelles, op. cit., p. 55-59. 
la experiencia ilustrarian la opinión pública y prepararian a la nación a recibir sin violencia las alteraciones y mejoras que conviniese hacer en las instituciones que había adoptado ${ }^{18}$.

A lo largo de los tres años de sesiones parlamentarias, la referencia a la cuestión de la reforma constitucional afloraría en repetidas ocasiones, generalmente al calor de las discusiones sobre otros temas, pero nunca fue un asunto debatido de manera formal y en exclusiva por las Cortes, prácticamente hasta principios del año 1823. Y eso que, apenas iniciadas las sesiones de la primera legislatura, el 18 de julio de 1820, el diputado Juan Francisco Zapata realizó la siguiente proposición a la Cámara:

En el art. 375 de la Constitución politica de la monarquía se dice: "hasta pasados ocho años después de haberse puesto en práctica la Constitución en todas sus partes, no se podrá proponer alteración, adición ni reforma en ninguno de sus artículos". En su consecuencia pido que las Cortes declaren que los ocho años que se prefijan en el artículo citado deben principiar desde el día 9 de julio del presente año, en que S.M. juró la Constitución política de la monarquía en el seno del Congreso"19.

La propuesta se tuvo en consideración como de primera lectura y regresó a las Cortes dos meses después, el 2 de septiembre, como segunda lectura. Sin embargo, no consta en los Diarios de Sesiones de Cortes -o al menos no lo he encontrado- que en algún momento se haya retomado el debate sobre esta cuestión.

Las causas de esta obtusa negativa han sido consideradas por la historiografia y por los propios diputados. El rechazo que el establecimiento en 1820 del régimen constitucional en España produjo en las cortes europeas, estaba basado en la circular que Rusia habia enviado al resto de soberanos. Pero también, en la tibieza con que Gran Bretaña acogió la revolución española, generando dudas acerca de la conveniencia de restablecer la Constitución de 1812 y el desenlace de esta acción ${ }^{20}$.

Aquellos que se negaban con rotundidad a la modificación de la Constitución aludian a que el artículo se refería expresamente a ocho años de puesta en práctica "en todas sus partes", por lo que debía ponerse el contador a cero desde 1820 en que volvió a proclamarse la Constitución, tal y como había planteado el diputado Zapata al inicio de las sesiones. Como he dicho, si bien hubo menciones tangenciales a la cuestión de la reforma durante las sesiones de estos años, éstas se insertaban normalmente en otras discusiones parlamentarias. En este sentido,

18 Ibídem, p. 70.

19 DSC, 18 de julio de 1820, p. 187.

20 La circular rusa al resto de cortes europeas data de 20 de abril de 1820, y a pesar de la insistencia en reclamar los principios de la Santa Alianza frente a la revolución española, ni Gran Bretaña, ni el resto de potencias europeas estuvieron de acuerdo con los planes rusos. Ulrike Schmieder, Prusia y el Congreso de Verona, Ed. del Orto, Madrid, 1998, p. 34. También Ivana Frasquet, "Restauración y revolución en el Atlántico hispanoamericano", Pedro Rújula y Javier Ramón Solans (eds.), El desafio de la revolución. Reaccionarios, antiliberales y contrarrevolucionarios (siglos XVIII y XIX), Editorial Comares, Granada, 2017, pp. 29-49. 
los debates acerca de las infracciones a la Constitución eran, por lo general, los más oportunos para referirse al tema de la modificación ${ }^{21}$.

Expondré un ejemplo al respecto. En la sesión del 18 de octubre de 1820, la comisión encargada del dictamen sobre los 69 diputados que firmaron el manifiesto presentado al rey en 1814 -el conocido como Manifiesto de los Persas-, examinó si estos se hallaban en el caso de ser considerados infractores a la Constitución y, por lo tanto, debía exigírseles la responsabilidad pertinente o, por el contrario, estimar la conveniencia de un perdón en aras de la reconciliación nacional 22 .

La cuestión se dirimió entre los que planteaban que las Cortes sí podían decretar una amnistía a los persas por razones de conveniencia pública y los que apreciaban que dicha resolución suponía modificar o derogar el articulado constitucional que exigía la aplicación de penas a los infractores al texto. Para esto último, como argumentaría uno de los líderes exaltados, Juan Palarea, no tenían los diputados los poderes especiales que se necesitaban, pues no habian transcurrido los ocho años requeridos en el artículo 375.

Por su parte, Martínez de la Rosa exigía observar la cuestión con ojos de legislador para buscar la conveniencia pública y la utilidad de la nación. Según el diputado, las Cortes no podian derogar ni modificar ninguna parte del texto constitucional en aquellos momentos, pero sí podian conceder un olvido a sus infractores haciendo uso de su prerrogativa para decretar amnistías ya que "el bien de la nación nos puede autorizar en circunstancias extraordinarias a suspender el brazo de la ley y a echar un velo sobre ella". Si bien al diputado tampoco le parecía acertado dispensar una absoluta impunidad ante semejante delito y pedía que se privase a los 69 persas de los empleos, honores y mercedes concedidas con motivo de su participación en la caída del régimen constitucional23.

Estrechamente relacionada con el tema de la modificación constitucional se encontraba la cuestión del llamado "plan de cámaras", que aludía expresamente a la división en dos cámaras del poder legislativo. Este proyecto se atribuía a la propuesta de las potencias extranjeras, particularmente de Gran Bretaña y Francia, para introducir una cámara de notables y ampliar los poderes del rey.

21 Sobre la cuestión de las infracciones sigue siendo de obligada consulta Marta Lorente Sariñena, Las infracciones a la Constitución de 1812: un mecanismo de defensa de la Constitución, Centro de Estudios Constitucionales, Madrid, 1988.

22 Son escasos los trabajos sobre el funcionamiento del Tribunal de Cortes encargado de enjuiciar a los diputados. En el caso de los persas, finalmente se les concedió un perdón general privándoseles de sus honores y empleos. Un estudio de caso sobre este tema puede encontrarse en el trabajo de José Antonio Pérez Juan, "Notas sobre el Tribunal de Cortes en el Trienio Liberal", en Ignacio Czeguhn y J. A. Pérez Juan (coords.), Reflexiones sobre la Justicia en Europa durante la primera mitad del siglo XIX, Ed. Club universitario, Alicante, 2010, pp. 191-221.

23 Aún así, el Martínez de la Rosa del Trienio estaba bastante lejos del diputado que fue en la anterior época constitucional cuando, a punto de cerrarse las sesiones en 1814, proclamaba: "El diputado de Cortes que contra lo prevenido en el art. 375 de la constitución, proponga que se haga en ella o en alguno de sus artículos alguna alteración, adición o reforma hasta pasados ocho años después de haberse puesto en práctica la Constitución en todas sus partes, será declarado traidor y condenado a muerte". DSC, 18 de octubre de 1820, p. 1753-54. 
Los liberales exaltados, como Romero Alpuente, detestaban siquiera considerar el tema, aludiendo al mismo como "la cosa peor del mundo" 24.

Pero también los moderados, como Argüelles, despreciaban la introducción de este plan, considerándolo un ardid de los absolutistas para "alucinar a los incautos" ante la imposibilidad de mudar el régimen por la misma vía que en $1814^{25}$. Y es que, tras estas afirmaciones asomaba una de las cuestiones fundamentales del liberalismo del Trienio, cual fue la desconfianza absoluta hacia Fernando VII como monarca constitucional. A veces sin tapujos, otras de forma velada, los diputados reconocían el incumplimiento de las promesas que el rey había promulgado en su decreto de 4 de mayo de 1814:

También en él se ofrecieron Cortes, libertad de imprenta, olvido de lo pasado y todo lo que en una célebre asamblea de la Europa se presentó por un ministro que quiso entonces justificar aquella contrarrevolución, como sólidas bases de un gobierno bien constituido [...] El trastorno del sistema constitucional se consumó por la cooperación de los que se persuadian que podía establecerse un gobierno racional por medio del poder absoluto. La añagaza de las Cámaras tiene por objeto reunir a los descontentos que quieren reformas ideales de cierta clase, contra el enemigo común, que es la Constitución. Destruida esta, el régimen arbitrario sucedería inevitablemente; y entonces ni las Cámaras ni otra alguna de las magníficas promesas que puedan haberse acompañado a aquella ilusión, tendría más garantías que lo ofrecido en el año 1426.

Como se ve, la cuestión sobre la posible reforma constitucional afloraba en los distintos debates parlamentarios, pero será cuando las potencias santoaliadas envien sus amenazantes circulares al gobierno español cuando se ponga en el centro de la discusión política. Pero, para entonces, la modificación se antojaba imposible, tanto para los que la hubieran deseado en otro tiempo, como para los que se oponian fervientemente a ella en todo momento.

Alcalá Galiano, reconociendo que no le hubiera disgustado una reforma del texto constitucional, afirmaba en sus Memorias que la modificación era imposible por varias razones. En primer lugar, porque la propuesta partía de la liga de monarcas legitimistas que carecian de derecho para hacerla, y porque su objetivo era que las Cortes se sometieran en este asunto a la voluntad del rey. En segundo lugar, porque era sabido que Fernando VII se había mostrado contrario a reinar bajo cualquier forma de sistema constitucional y, en tercer lugar, porque los dos grandes partidos existentes -absolutista y constitucional- rechazarian, cada uno por sus razones, una monarquía parecida a la de la carta otorgada francesa ${ }^{27}$.

24 Pedro J. Ramírez, La desventura de la libertad. José María Calatrava y la caida del régimen constitucional español en 1823, La Esfera de los libros, Madrid, 2014, p. 46.

25 A. Argüelles: "La íntima persuasión en que están los enemigos de la Constitución de que no es posible realizar un trastorno por los mismos medios que en el año de 14, y menos cuando no pueden reproducirse los prestigios que facilitaron la empresa de aquella época funesta, han ideado presentar como aliciente el establecimiento de las dos Cámaras". DSC, 27 de marzo de 1822 , p. 599.

26 Ibídem, p. 600.

27 Memorias de D. Antonio Alcalá Galiano, op. cit., p. 435. 
Bien sabía Alcalá Galiano, al igual que Argüelles, que las críticas a la posición intransigente de las Cortes abocaban a un conflicto armado, puesto que las potencias santoaliadas lo utilizarian como argumento para forzar una invasión. Aunque en este punto confiaban en la mediación de Gran Bretaña, a cuyos intereses particulares no convenía una España vinculada política y familiarmente a la Francia legitimista, para muchos era evidente que los soberanos europeos no deseaban una mudanza constitucional, sino que sus verdaderas intenciones eran ayudar al rey a recobrar su autoridad en plenitud.

En cualquier caso, el liberalismo español se veía atrapado en una difícil situación, puesto que acceder a la voluntad de los franceses no sólo suponía entregar poderes a Fernando para que volviera a gobernar como antes de 1820, sino aceptar el cuestionamiento de la doctrina que había asentado el régimen liberal: la de la soberanía nacional. Las invectivas lanzadas contra el liberalismo en este sentido recalcaban su exceso de apego al dogma de la soberania, su tozudez en impedir una modificación constitucional que evitara la guerra y mantuviera la independencia y el honor de España. Para Alcalá Galiano, los tenazmente adictos a un dogma abstracto eran los gobiernos europeos reunidos en Verona, que se empeñaban en sustentar que "solo procediendo del trono son legitimas las Constituciones"28. Pero para eso, como bien sabía el diputado, era preciso que el rey consintiera en darla. Y Fernando VII, de todos era conocido, no era dado a aceptar limites a su poder como tampoco disponía de un partido en las Cortes -ni fuera de ellas- lo suficientemente numeroso para apoyar con cierta garantía de éxito una reforma constitucional.

De este modo, los comentarios dentro y fuera de las Cortes sobre la posible reforma constitucional se ciñeron, generalmente, a plantear si el limite temporal establecido en el artículo 375 habia ya transcurrido o no. Los que hubieran consentido en una modificación del texto consideraban que, en 1823, podian estimarse como transcurridos cinco años a contar desde la sanción del texto en 1812. Así, computaban dos años cumplidos en la primera época constitucional (1812-1814) y otros tres en la segunda (1820-1823), por lo que tan sólo quedarian tres más para poder iniciar el proceso de reforma. Aún así, consideraban que la legislación vigente impedia en esos momentos variar el texto constitucional y que, de haberlo hecho, habrian infringido la ley. De esta manera lo consideraba Argüelles cuando le escribia a su amigo inglés, lord Holland, sobre esta cuestión:

En las Cortes no puede agitarse esta cuestión legalmente porque nuestros poderes no nos lo permiten hasta pasados los ocho años; y un acto de ilegalidad no es seguramente de corregir errores en medio de la agitación de las pasiones y de los partidos. Este período de reforma legal, mylord, está ya muy próximo para que pueda justificarse el empeño que se manifiesta por los gobiernos extranjeros ${ }^{29}$.

28 Ibídem, p. 436. Como describiría en sus memorias: "Fernando VII, fuerza es repetirlo, no quería dar ni recibir constituciones, sino reinar como habían reinado su padre y abuelos [...] y reponerlo todo a su antiguo ser".

29 Carta de Agustín Argüelles a lord Holland, Madrid, 8 de febrero de 1823. Citada en Manuel Moreno Alonso, "Confesiones políticas de Don Agustín de Argüelles", Revista de Estudios Politicos (Nueva Época), n 54, noviembre-diciembre, 1986, pp. 249-250. 
El diputado reconocía, a la altura de 1823, que la Constitución de Cádiz adolecía de ciertos "vicios" que fueron inevitables cuando se formó, porque se carecía entonces de los conocimientos exactos sobre el sistema representativo, pero consideraba que las potencias extranjeras debían ceder en algo por su parte hasta que llegara la época señalada en el propio texto para su modificación. No era posible realizar una reforma sin convulsiones y con probabilidad de éxito si no se discutian primero las propuestas por la imprenta y después en las Cortes.

En este sentido, aunque no se convocó -como en 1809- a una consulta general al reino, algunas de las opiniones sobre la conveniencia de reformar la Constitución procedieron de publicistas que comentaron la cuestión en sus escritos. Alejandro Oliván, un veterano de la guerra de 1808 -que acabaría siendo un destacado político moderado, inclusive ministro en 1847-, publicó en 1823 un opúsculo titulado Sobre modificar la constitución. En él acusaba a las Cortes de haber legislado en menos de dos años lo que debía haberse hecho en quince y, sin embargo, "haber cerrado el camino a toda modificación de la Constitución politica"30.

El texto realiza un recorrido por los principales acontecimientos políticos desde 1820, criticando los excesos de los exaltados, la injerencia del legislativo en el ejecutivo y la división del liberalismo. Para Oliván, la solución ante la amenaza de guerra era convertir al Consejo de Estado en una verdadera cámara deliberativa, que cumpliera las funciones de senado y estuviera compuesta por diputados propietarios ${ }^{31}$. Estas reformas debian haberse llevado a cabo desde el mismo momento en que se restableció la Constitución, lo que hubiera evitado la deriva anárquica del sistema político en España. Sin embargo, el autor no se detiene a explicar cómo hubiera sido eso posible sin ir en contra de los preceptos constitucionales.

Al parecer, el opúsculo de Oliván tuvo cierta circulación en los dias siguientes y fue contestado desde la prensa. En El Universal, aparecieron varios artículos dedicados a impugnarlo en números sucesivos. En ellos se criticaba la posición de Oliván, al que se acusaba de libelista, y se realizaba una defensa cerrada de la Constitución como la única "ley conocida" y que en el momento podía salvar a la nación. Y aunque se reconocian en ella ciertas imperfecciones,

\footnotetext{
30 El texto está firmado como "un español". Para la autoría contrastada sigo a P. J. Ramírez, La desventura de la libertad, op. cit., nota 46, p. 1039. Sobre modificar la Constitución, Imprenta de la Calle de Atocha a cargo a don Manuel de Lesaca, Madrid, 1823. Recuperado de internet en la Biblioteca Digital Hispánica. En respuesta a las críticas que se vertieron en los periódicos a este folleto, el autor escribió otro en el que reconocía que no había desvelado su autoría porque no era hombre de letras, y que no lo hacía tampoco en este para no pecar de modesto después del éxito de su primer artículo. Y añadia: "Digo sin embargo que mi nombre está libre de tacha, que en la guerra de la independencia tomé las armas a favor de ella [...] que desde entonces he profesado constantemente principios liberales aunque no exagerados", p. 2.

31 Al respecto, Oliván insistía en poner en práctica el artículo 92 de la Constitución que se hallaba suspendido de su sanción, aquel que exigía una renta mínima para ser diputado y que hubiera compuesto las Cortes de hombres propietarios, arraigados en su comunidad con intereses que proteger: "vale más un hombre arraigado que no sepa, que un sabio sin arraigo". Sobre modificar la Constitución, op. cit., p. 9.
} 
también se asentaba que abria "la senda que conduce a su rectificación y mejora"32.

En respuesta a las criticas recibidas, Oliván publicó un nuevo folleto bajo el título Contestación del autor del papel titulado sobre modificar la Constitución a las impugnaciones que se le han hecho en los periódicos ${ }^{33}$. Además de defenderse de los ataques a sus propuestas, insistía en que las circunstancias presentes eran las más adecuadas para la necesaria reforma constitucional. Y afirmaba: "Si una crisis politica producida por la irrupción extranjera dio lugar a la formación de la Constitución, que la crisis presente sirva para facilitar su perfección y mejora" ${ }^{4}$.

Pero el debate fuera de las Cortes no era cuestión solo de periodistas y ciudadanos comprometidos con la moderación constitucional. Ya desde 1821 como es conocido- juristas como Ramón de Salas habían criticado duramente el limite temporal de ocho años impuesto para iniciar el proceso de reforma.

Como los hombres no son infalibles, ni sus obras perfectas, siempre, si es posible, deben reservarse un medio para corregirlas; y me parece que no es muy conforme a esta máxima de prudencia el artículo 375, [...] porque creo que esta disposición, cuyo objeto laudable, es sin duda dar a la Ley Fundamental el carácter de estabilidad que debe tener, hace imposible, por lo menos en un siglo, la corrección de cualquiera defecto que la experiencia y el tiempo puedan hacer ver en nuestra Constitución que, al fin, como obra de hombres, no es absolutamente perfecta ${ }^{35}$.

Por lo que se aprecia, lo que muchos hubieran deseado es que se alterara el texto constitucional sin observar su procedimiento de reforma. Es decir, aquello que Carl Schmitt denominaría más tarde una "reforma inconstitucional de la Constitución"36. En esa misma línea insistía el embajador británico en Madrid a principios de 1823, lord Fitz-Roy Somerset. A este le desesperaba la pasividad de las autoridades españolas ante la amenaza francesa y no comprendía por qué no se avenían a una modificación constitucional que hubiera resuelto la cuestión. Para el diplomático, la falta de iniciativa del consejo de Estado para imponer la reforma le parecía estar anclada en "absurdos escrúpulos para mantener la legalidad"37. Respetar el articulado constitucional en este punto le parecía un pretexto para mantener el inmovilismo. Por lo demás, quien demostró verdadera pasividad ante los acontecimientos fue Gran Bretaña. Su máxima preocupación era mantener a Francia alejada de las ex colonias españolas y evitar que se

32 El Universal, 1 de abril de 1823. Es más que probable, por las expresiones utilizadas y el tono de la pluma, que el impugnador de Oliván en el periódico fuera Antonio Alcalá Galiano.

33 Publicado el 10 de abril de 1823, mismo día que se consignaba la entrada de las tropas francesas en España. El texto lo he consultado en la Biblioteca Digital Hispánica.

34 Contestación del autor del papel titulado sobre modificar la Constitución a las impugnaciones que se le han hecho en los periódicos. Imprenta de la Calle de Atocha a cargo a don Manuel de Lesaca, Madrid, 10 de abril de 1823, p. 18.

35 De las Lecciones de Ramón de Salas, citado en J. Ruipérez, "Una cuestión nuclear para la teoria del derecho constitucional”, op. cit., p. 469.

36 Carl Schmitt, Teoría de la Constitución, Madrid, Alianza Editorial, 1983, p. 115 y ss.

37 Citado en Juan Francisco Fuentes, "El Trienio liberal en la correspondencia del duque de Welllington", Boletín de la Real Academia de la Historia, CLXXXVI, 3, Madrid, 1989, pp. 407-442. 
convocara un congreso para tratar la futura situación de América, como deseaba Chateaubriand.

\section{LA CUESTIÓN AMERICANA Y LA CONSTITUCIÓN DE CÁDIZ}

Teniendo en cuenta lo anterior, la reposición del sistema constitucional en 1820 supuso, para los americanos en particular, retomar la esperanza en la aplicación de unas políticas liberales que reconocieran mayores derechos $\mathrm{y}$ autogobierno para sus territorios ${ }^{38}$. Entre los primeros de esos derechos se encontraba la consecución de una verdadera igualdad jurídica entre americanos y españoles. Pero también, la necesidad de terminar con una guerra civil que duraba ya diez años. En los gobiernos liberales del Trienio se depositaron no pocos sueños y muchos anhelos al respecto.

La postura oficial del gobierno y las Cortes durante estos años apostó por la conciliación y se apoyó en la Constitución de Cádiz como el elemento vertebrador de lo que eufemísticamente se llamó "la política de pacificación". Como se ha dicho, la prioridad era acabar con la guerra civil que desangraba a los españoles americanos y europeos desde 1814 y conseguir una paz duradera. Para ello, los americanos disidentes debían jurar obediencia al texto constitucional y regresar al seno de la monarquía que, cual madre comprensiva, extendería un perdón general. Esta posición se adoptó, en principio, por todos -gobierno, consejo de Estado, monarca y Cortes- desde la convicción de que los americanos habian errado en su conducta al tratar de independizarse. La paz solo sería posible si estos reconocian su vínculo constitucional con España y aceptaban las ventajas y libertades que se les ofrecian.

El plan podría haber funcionado salvo por dos cuestiones que no se tuvieron en cuenta en aquel momento. La primera fue que la mayoria de los territorios que habian sostenido la guerra contra las armas españolas desde 1814 -o incluso antes-, gozaban ya de mayor autogobierno del que el texto constitucional les concedia o bien se hallaban de facto independizados. La segunda, que no se contó con la actitud armígera e intransigente de Fernando VII en un asunto con el que jamás iba a condescender. En la proclama que el rey dirigió a los habitantes de Ultramar el 31 de marzo de 1820, se fijaba la "versión oficial" que se mantendría durante estos años: los derechos y libertades de América quedaban garantizados por la Constitución pero, advirtiendo amenazantemente que, en caso de que los americanos no se avinieran al real ofrecimiento, la guerra civil continuaria.

De este modo, el rey -junto a su consejo de Estado- tomó la iniciativa en lo que a la solución para América se refiere, pues antes de que las Cortes se reunieran, en abril de 1820, ya estableció una vía pacificadora consistente en el envío de comisionados a los territorios en guerra para conseguir el cese de las hostilidades y el retorno de estos al seno de su monarquía. Ahora bien, Fernando VII se reservaba la posibilidad de sostener el conflicto armado si los americanos no admitian su propuesta. A su alrededor, la Junta Provisional, el Consejo de Estado y los ministros, mantendrán la certidumbre de que la sola aceptación del

38 Jaime E. Rodríguez O., El nacimiento de Hispanoamérica. Vicente Rocafuerte y el hispanoamericanismo, 1808-1832, México, Fondo de Cultura Económica, 1980, p. 59. 
texto constitucional y la amnistía decretada serian suficientes para que los americanos desistieran en sus pretensiones de independencia ${ }^{39}$.

Por su parte, la mayoría del liberalismo en las Cortes participará de esta posición mediadora que veía en la Constitución de 1812 el remedio reparador que restañaria las heridas entre los hermanos americanos y españoles. Al menos en una primera etapa en la que todavía se confiaba en la promesa del rey de ser verdaderamente constitucional ${ }^{40}$. Desde el principio, por tanto, la solución dentro del marco constitucional doceañista fue la única contemplada por los gobiernos del Trienio y a la que, paradójicamente, Fernando VII se aferrará con fuerza ante la posibilidad de que las Cortes aprueben cualquier acuerdo en el que se atisbe, si quiera mínimamente, una concesión de mayor autogobierno para los americanos.

Así pues, la Constitución de Cádiz se situará en el centro del debate político sobre la cuestión americana. Con un encaje dificil en la realidad de la monarquía española de los años veinte, hasta sus más firmes defensores reconocían que tal vez no era la más adecuada en aquellas circunstancias, pero nadie pensaba en modificarla. Sin embargo, el modelo territorial de Estado que diseñaba ya no era viable para aquellos americanos que, ante la amenaza de guerra y revolución, propusieron soluciones de corte descentralizador no contempladas en el texto constitucional.

\subsection{Un plan de monarquias para América}

Los primeros diputados americanos que asistieron a las Cortes habian sido elegidos en Madrid el 28 de mayo de 1820. Lo hicieron en calidad de suplentes, siguiendo la convocatoria que al efecto había publicado la Junta Provisional y a la espera de que se celebraran las elecciones en América y llegaran los representantes propietarios. El grueso de la diputación americana estará conformado por novohispanos y centroamericanos, más algunos otros diputados elegidos en las zonas que todavía se mantenían fieles a la monarquía. Desde el inicio de la legislatura, los mexicanos tomarán la iniciativa para colocar la resolución a la crisis de Ultramar en la agenda política de los debates. Sus propuestas irán encaminadas a conseguir un aumento de la representación parlamentaria, así como mayor autonomía y autogobierno para sus territorios a partir de la ampliación efectiva de las instituciones existentes en la Constitución: los ayuntamientos constitucionales y las diputaciones provinciales ${ }^{41}$.

39 La Junta Provisional manifestaba en un informe: "la pacificación de la América es ya mas una obra de politica que de la fuerza y (...) solo la Constitución puede restablecer los lazos fraternales que la unían con la madre patria".

40 Ascensión Martínez Riaza ha señalado acertadamente que en la primera etapa negociadora (entre marzo de 1820 y finales de 1821) todas las instituciones implicadas apostarian por la negociación bajo la aceptación sin cuestionamiento de la Constitución y a riesgo de retomar la vía armada. La segunda etapa (inicios de 1822 hasta finales 1823) relanzaba la negociación con el reconocimiento de la existencia de los gobiernos americanos y con la esperanza de obtener tratados ventajosos. Ascensión Martínez Riaza, "Para reintegrar la Nación». El Perú en la política negociadora del Trienio Liberal con los disidentes americanos, 1820-1824", Revista de Indias, vol. LXXI, no 253 (2011), pp. 647-692.

41 Sobre las propuestas americanas en estas Cortes puede consultarse: I. Frasquet, "La cuestión nacional americana en las Cortes del Trienio" en J. E. Rodríguez O. (ed.) Revolución, 
Para comprender las propuestas que los americanos realizaron en las Cortes del Trienio es preciso tener presente la concepción de la soberanía que mantenian respecto a los poderes provinciales. Para ellos, la diputación tenía capacidad soberana, puesto que se elegía mediante el mismo proceso electoral -sistema indirecto en tres niveles- que las Cortes de la nación. Es decir, los electores de provincia en el segundo nivel que escogian a los vocales de la diputación también sufragaban para la elección de los diputados a Cortes. De este modo, la legitimidad que se le concedia al sistema de elección del poder legislativo, las Cortes, se vinculaba a la capacidad soberana de los individuos del cuerpo legal que ejercían el sufragio. Un diputado mexicano, Pablo de la Llave, fue quien ligó la soberanía al individuo argumentando razones demográficas para la elección de diputaciones, pues según su opinión, estas deberian elegirse en función de "la razón compuesta del número de habitantes y extensión del terreno que ocupan" 42 . En este sentido, en el planteamiento de los diputados americanos, las diputaciones provinciales eran igual de soberanas que las Cortes. Así pues, la idea de soberanía enlazada a la de representación en el nivel provincial evidenciaba para los americanos un principio plenamente representativo y descentralizador. De aquí surgirá la más interesante propuesta de organización federal de la monarquía española en estos años.

La legislatura iniciada en marzo de 1821 sería crucial para los planes americanos. En el discurso inaugural, el rey mantuvo la politica oficial sobre la pacificación, dando cuenta del armisticio firmado con Bolivar y remarcando la obediencia a la Constitución como principio fundamental. El nuevo período de sesiones comenzaba con un cambio importante del gabinete ministerial. Fernando VII, en protesta por la actuación del gobierno anterior y alegando ultrajes cometidos contra él, obligó a la sustitución de sus miembros por otros más afines a su persona ${ }^{43}$. Al frente del ministerio de Estado situó a Eusebio Bardaji quien, al igual que Ramón Feliu en Ultramar, desempeñarían en los meses siguientes un papel protagonista en la búsqueda de una solución negociada para la crisis americana.

independencia y las nuevas naciones de América, Fundación Mapfre Tavera, Madrid, 2005, pp. 123-157. De la misma autora, "Ciudadanos ya tenéis Cortes". La convocatoria de 1820 y la representación americana”, en J. E. Rodríguez O. (coord.), Las nuevas naciones. España y México, 1800-1850, Madrid, Fundación Mapfre, 2008, pp. 145-167. Braz A. Brancato, "Las Cortes españolas del Trienio Liberal y la cuestión del reconocimiento de las independencias hispanoamericanas", Anuario de Estudios Bolivarianos, no 14 (2007), pp. 41-55. Salvador Broseta Perales, Autonomismo, insurgencia, independencia. América en las Cortes del Trienio Liberal, 18201823, Ayto. de Cádiz, Cádiz, 2012. Jaime E. Rodríguez O., "La transición de colonia a nación: Nueva España, 1820-1821", Historia Mexicana, XLIII:2, 1993, pp. 265-322.

42 Ni la Constitución ni el Decreto de 23 de mayo de 1812 -que comprendía la instrucción de la formación de las diputaciones provinciales- decían nada al respecto de que se precisaba una fórmula que incluyera la extensión del territorio y la población que lo habitaba para la conformación de gobiernos provinciales. DSC, 30 de abril de 1821, p. 1360.

43 Se trataba de la famosa "coletilla" insertada en el discurso inaugural del rey: "Me es preciso, sin embargo, hacer presente, aunque con dolor, a este sabio Congreso, que no se me ocultan las ideas que algunos mal intencionados que procuran seducir a los incautos, persuadiéndoles que mi corazón abriga miras opuestas al sistema que nos rige; su fin no es otro que el de inspirar una desconfianza de mis puras intenciones y recto proceder. [...] pero no debo callar hoy al Congreso [...] que aquellos ultrajes y aquellos insultos no se hubieran repetido segunda vez si el poder ejecutivo tuviese toda la energía y vigor que la Constitución previene y las Cortes desean". DSC, 1 de marzo de 1821, p. 19. 
Para los americanos, un momento crucial se produjo el 3 de mayo de 1821 . Ese día, un diputado venezolano, Felipe Fermín Paul, intervino en las sesiones para exponer unas proposiciones relativas a su patria. El armisticio expiraba a finales de mes y el diputado esperaba que las Cortes tuvieran en consideración esta circunstancia para instar al gobierno a que se prorrogara. Lo destacable de esta intervención fue el apoyo que recibió de parte del conde de Toreno quien, a raíz de la misma, propuso la formación de una comisión mixta "compuesta de diputados europeos y de Ultramar, que manifestasen al Congreso lo que creyesen más conveniente, a fin de que todo concluya del modo más favorable". El tema americano había llegado al centro del debate político cuando uno de los líderes del liberalismo español llamaba la atención sobre el mismo como una cuestión esencial de la monarquía. Y añadia: "y si las Cortes dan fin a un negocio de tanta importancia antes de cerrarse las sesiones, habrán logrado hacer, como ha dicho el señor preopinante, una cosa magnífica que completará cuanto hasta aquí han hecho"44.

Pareciera que el conde de Toreno hablara en clave, al menos para aquellos que desconocian las relaciones que los americanos estaban tejiendo con el liberalismo peninsular desde meses atrás. Sin embargo, en las semanas siguientes se desvelaría el fruto de tan peculiar alianza. Apenas unos días antes de la formación de esta comisión mixta, había llegado a Madrid el grueso de los diputados propietarios mexicanos. Las noticias que portaban eran lo suficientemente importantes para acelerar la solución política a la crisis americana. El 24 de febrero anterior, el comandante Agustín de Iturbide había proclamado el Plan de Iguala en el que se consignaba la independencia de Nueva España bajo la forma monárquica y constitucional de gobierno, reservando el trono a Fernando VII u otro miembro de su familia ${ }^{45}$. Pero, de momento, esta información se reservó y no fue trasladada al gobierno.

Las reuniones de esta comisión cobrarían un protagonismo inusitado en las semanas siguientes, tanto por los temas que en ella se trataron como por el secretismo con que se condujeron. Según Lucas Alamán tenían lugar en casa de los mexicanos marqués del Apartado y Francisco Fagoaga, en la madrileña calle del Turco ${ }^{46}$. En estas se discutió acerca del famoso "plan de Cortes" que

44 DSC, 3 de mayo de 1821, p. 1389. La comisión se formó al día siguiente con los siguientes miembros: por parte peninsular el conde de Toreno, José María Calatrava, Juan Antonio Yandiola y Andrés Crespo Cantolla. Por el lado americano: Lucas Alamán, Francisco Fagoaga, Bernardino Amati, Lorenzo Zavala y Felipe Fermin Paul. DSC, 4 de mayo de 1821, p. 1406.

45 Los novohispanos ya sabian de estas novedades por su correspondencia particular y porque los diputados recién llegados habian contado que Iturbide les había enviado su proyecto con la intención de que no se embarcaran para las Cortes y que formaran ellos mismos un congreso en Veracruz que consolidara la independencia nacional proclamada en el plan de Iguala. Fue Manuel Gómez Pedraza, elegido diputado por México, quien daría cuenta de estos detalles posteriormente en su Manifiesto que Manuel Gómez Pedraza, ciudadano de la República de México, dedica a sus compatriotas; o sea una reseña de su vida pública, Imprenta de Benjamin Levy, Nueva Orleans, 1831, pp. 7-9. Biblioteca Digital UANL (recuperado de internet. 15 de junio de 2019). Por otro lado, Mariano Michelena, diputado mexicano por Valladolid de Michoacán, ya había adelantado a su ayuntamiento en una carta de 25 de abril, que se estaba formando un proyecto monárquico para México y que sólo esperaban a la llegada de los diputados propietarios para que se sumaran al mismo. DSC, 4 de junio de 1821, p. 2046.

46 Lucas Alamán, Historia de Méjico desde los primeros movimientos que prepararon su independencia en el año de 1808 hasta la época presente. Vol. V, Cap. VI. Recuperado de internet en la Colección Digital de la Universidad Autónoma de Nuevo León. 
configuraba la monarquía española como una federación de reinos, coronados por infantes borbónicos y cuya parte americana se compondría de tres sedes en México, Lima y Santa Fe de Bogotá. En cada una de estas sedes existiría una sección de cada uno de los tres poderes constitucionales, siendo las Cortes generales de la nación, residentes en Madrid, las que tendrían la última palabra en materias fundamentales ${ }^{47}$.

El embajador francés en Madrid, vizconde de Montmorency-Laval, dio cuenta en su correspondencia del 18 de mayo de lo sucedido en una de las más importantes reuniones de esa comisión:

En la noche del 16 de mayo se reunió la comisión de Ultramar con una especial, nombrada por las Cortes, para estudiar la mejor manera de conciliar al Gobierno español con las colonias de América. Varios ministros asistieron a la conversación. El interino de Ultramar, señor Feliu, manifestó que S.M., en vista de la situación que atravesaba la América y buscando los medios más eficaces para impedir la separación de las colonias, estaba dispuesta a enviar a México a uno de los infantes en calidad de virrey, quien gobernaría el virreinato bajo el sistema constitucional que regía en la Península; agregando que el monarca estaba preparado para entenderse en este particular con las Cortes ${ }^{48}$.

Sin duda se trataba de un plan para emancipar América con el consentimiento de la monarquía. Lo que algunos llamaban "la independencia pactada" y que venía gestándose desde los inicios de la primera legislatura. El proyecto, según relató después Lucas Alamán, se concibió antes de que el capitán general Juan O’Donojú se embarcase para Nueva España por esos días de mayo de $1821^{49}$ y lo definía como "una gran confederación con el rey de España a su cabeza".

La cuestión primordial en este asunto era convencer a Fernando VII de que aceptara una solución monárquica y descentralizada para América, consintiendo en el envío de los infantes para reinar allí en su nombre. El plan le fue presentado junto con la proposición de convocar unas Cortes extraordinarias en las que se discutiria y aprobaría. Según Michael Costeloe, el rey fue sometido a un interrogatorio el día 24 de mayo para conocer su opinión:

- ¿Le habian dicho sus ministros algo acerca del envío de infantes a América?

- ¿Se opondría a la partida de los infantes por considerarla inconstitucional y para ganar tiempo?50

47 Sobre este plan es de indiscutible referencia Jaime E. Rodríguez O., "La transición de colonia a nación", op. cit., p. 287 y ss. También Alberto Navas Sierra, Utopía y atopía de la Hispanidad. El proyecto de Confederación Hispánica de Francisco Antonio Zea, Madrid, Ediciones Encuentro, 2000.

48 La transcripción ha llegado hasta nosotros a través del estudio de Carlos A. Villanueva, La monarquía en América. Fernando VII y los nuevos estados, París, Paul Olendorff, 1911, p. 60.

49 Lo que corroboraba Mariano Michelena al afirmar en las Cortes: "es de advertir que en el navío Asia van ya algunos oficiales que están enterados de lo que se trata, y del giro que hasta su salida llevaba este negocio". DSC, 4 de junio de 1821, p. 2046.

50 No he podido conseguir el documento que cita Costeloe en su trabajo ni averiguar quién o quiénes presentaron el cuestionario al rey. A la primera pregunta respondió: "Lo han insinuado, 
La respuesta de Fernando fue de rechazo frontal a estas propuestas. Entre las razones que adujo para resistirse al envío de infantes a América se encontraba su convencimiento de que todo se trataba de una intriga para alejar a los infantes de su lado, sobre todo a Carlos María Isidro, a quien consideraba su heredero. Además del recelo que sentia hacia Francisco de Paula quien, al parecer, soñaba con poder ser rey de México.

Lo interesante de este cuestionario, aunque breve, es la información que revela acerca de las opiniones que rodeaban al rey. En primer lugar, la insidiosa segunda pregunta consideraba ya como "inconstitucional" la propuesta del plan de secciones americanas. Quien se la formuló, sin duda deseaba conducir los ánimos del rey en una determinada dirección. En segundo lugar, desvela la maquinación para conseguir retrasar la aprobación del plan de la comisión, lo que evidencia lo cerca que estuvo de salir adelante ${ }^{51}$. En esta situación, no es de extrañar que Fernando VII desvariara con una conspiración urdida entre el gobierno británico y su ministro de Estado, Bardají, con la finalidad de "hacerle salirse de la Constitución para perderle y llevarle a la guillotina"52.

Los motivos que llevaron al rey a no dejarse convencer con la idea de enviar a los infantes a América se nutrieron también de una contingencia histórica favorable. Dos días después de la reunión nocturna de la comisión que relataba el embajador francés, llegaba por conducto de La Habana la noticia de la proclamación del Plan de Iguala en México. Las cosas habian cambiado. El más fiel de los virreinatos, la joya de la corona, se insurreccionaba sin atender al llamado constitucional del rey. Si en algún momento había existido la posibilidad de que Fernando aceptara el plan federal americano, a partir de aquí, se desvaneció totalmente.

La intransigencia del rey se cifró en la negativa a convocar las Cortes extraordinarias donde se iba a discutir el tema americano. El asunto era de tal importancia que apareció en los debates de las sociedades patrióticas. En la Fontana de Oro, el 21 de mayo de 1821, un ciudadano desde la tribuna ligaba la cuestión de la convocatoria extraordinaria a la urgente necesidad de acabar con la guerra en América, reconociendo su independencia y consintiendo en el envio de infantes. Parecía evidente que, en Madrid, todo el mundo conocía el contenido del famoso plan de secciones americanas que estaba llamado a ser el dictamen oficial de la comisión mixta de las Cortes sobre esta cuestión: "las Cortes

pero no de oficio". La segunda fue contestada con un escueto "Sí". M. P. Costeloe, La respuesta a la independencia. La España imperial y las revoluciones hispanoamericanas, 1810-1840, México, FCE, 1989, p. 231.

51 Al parecer era cierto que, en las reuniones de la comisión, los ministros de Fernando consintieron con el plan de federalización de la monarquía. Más allá de lo transmitido por el embajador francés a su gobierno, el propio conde de Toreno lo confirmó en sede parlamentaria: "La comisión [...] discutió en varias conferencias las cuestiones que le parecieron más propias para conseguir el gran fin que todos nos proponemos: las examinó en unión con los ministros de S.M., los cuales al principio convinieron enteramente con los dictámenes que en general se sostuvieron". DSC, 24 de junio de 1821, p. 2448.

52 Carlos A. Villanueva, La monarquía en América, op. cit., pp. 72 y ss. Ver también M. P. Costeloe, La respuesta a la independencia, op. cit., p. 231. 
españolas tendrán que estudiar el asunto a propuesta de los diputados americanos de su seno" 53 , señalaba el orador.

\subsection{La inconstitucionalidad del proyecto federal}

El verano de 1821 será de gran agitación social y política, y las noticias sobre América se situaron en su epicentro. El armisticio con Bolivar se rompió, a lo que siguieron las derrotas de las armas españolas y el siempre amenazante reconocimiento de las independencias americanas por parte de las potencias extranjeras. Cuando iniciaba el último mes de sesiones de la legislatura, los diputados americanos exigieron a las Cortes que se diera cuenta oficialmente de las noticias sobre la rebelión acaecida en Nueva España. Noticias que, como se ha visto, ya sabian por su correspondencia particular, al igual que Fernando tuvo conocimiento de ellas a finales de mayo anterior. Todos habian guardado silencio.

El 4 de junio el nuevo ministro de Ultramar, López Pelegrín, quien había tomado posesión el día anterior, leyó los partes enviados por el virrey de México sobre la insurrección de Agustín de Iturbide. Los americanos en las Cortes tomaron la palabra para apremiar a la comisión y al gobierno a aprobar las medidas ejecutivas y radicales que eran necesarias para la total y completa pacificación de América. Estas se referian, claro está, al plan federal que ya se encontraba a punto de ser expuesto en la cámara. Ajenos todavía a las consecuencias que el cambio ministerial tendría para sus planes ${ }^{54}$, los debates de esos dias muestran la gran confianza que los diputados mexicanos mostraron ante la aprobación del proyecto para América55. Pero este convencimiento se fue desvaneciendo conforme avanzaba el mes de junio por varios factores.

Por un lado, la abierta discrepancia en la adopción de algunas de las bases del proyecto entre los propios americanos. En una carta enviada por un diputado de Puebla se explicitaban las desavenencias de los diputados de La Habana y de Yucatán a vincularse al gobierno mexicano, según indicaba el plan. Y, al mismo tiempo, reconocía que el resto de representantes -principalmente del Cono Sur-

53 Alberto Gil Novales, Las sociedades patrióticas (1820-1823), tomo I, Editorial Tecnos, Madrid, 1975, p. 623.

${ }^{54}$ La sustitución de Feliu, hombre afin a los planes de la comisión mixta, por López Pelegrín, fue trascendental en el giro copernicano que tomaron los acontecimientos sobre este asunto. El nuevo ministro, en la primera reunión de la comisión a la que acudió, se opuso abiertamente a las bases del plan federal, indicando que el ministerio contestaria confidencialmente a esas propuestas. Sin duda, Fernando VII acertó con el cambio de titular en la secretaría de Ultramar para frenar los planes federales del liberalismo, tanto peninsular como americano. Las referencias a esto en Idea general sobre la conducta politica de D. Miguel Ramos de Arizpe, natural de la provincia de Coahuila, como diputado que ha sido por esta provincia en las Cortes generales $y$ extraordinarias, y en las ordinarias de la Monarquía española desde el año de 1810 hasta el de 1821, Imprenta de Doña Herculana del Villar y socios, México, 1822, p. 18.

55 No sólo por la correspondencia particular sabemos de la confianza en la aprobación del plan, sino también por algunas propuestas, como la de Juan Gómez Navarrete, que pedia a las Cortes que se fuera aprestando un barco para que, en cuanto éstas aprobaran el proyecto, se comunicara de inmediato a Nueva España. La solicitud, que no fue admitida a discusión, rezaba: "que lleve la noticia de que en las Cortes se está tratando a propuesta de los diputados de Ultramar de un plan de gobierno que haga compatible la observancia de la Constitución con la enorme distancia que separa aquellas provincias de la metrópoli". Archivo del Congreso de los Diputados, Serie General, leg. 22, nº 19, numerada 6. (En adelante ACD) 
hallaban cierta dificultad en concordar con el plan propuesto, hasta el punto de que las acaloradas discusiones entre los americanos habían estancado la negociación en un punto muerto y "escandalizado a los diputados de España"56.

Por otro, el 20 de ese mes el ministro de Estado, Eusebio Bardají, adelantándose a la presentación del dictamen de la comisión de Ultramar en las Cortes, le envió sus observaciones sobre el proyecto en las que detallaba los obstáculos que impedian la aprobación del informe de la comisión. Esta maniobra de clara injerencia del ejecutivo en el legislativo fue suficiente para evitar la discusión del plan americano en las Cortes. En su exposición el ministro objetaba argumentos sustanciales sobre la inconstitucionalidad del proyecto, puesto que en él se planteaba una mudanza del sistema político de la monarquía. Bardaji confesaba que el proyecto le había sido remitido confidencialmente por la comisión y él se lo había presentado a Fernando VII. En este plan se habian encontrado obstáculos imposibles de remover. A saber:

$1^{\circ}$. Que ni el Rey ni el Ministerio pueden hacer ni harán jamás cosa alguna contraria a la Constitución: y la comisión no desconocerá que por sólidas y plausibles que sean las razones de justicia o de necesidad que la hayan conducido a la adopción de las bases referidas; estas alteran o destruyen varios artículos constitucionales.

$2^{\circ}$. Que podría ser de un ejemplo funestísimo el que las Cortes hicieran aquello para lo cual es indudable que no tienen poderes los Diputados.

$3^{\circ}$. Que para una novedad de tamaña importancia no está bastante preparada la opinión pública en la Península, ni tal vez en las Américas.

$4^{\circ}$. Que para no adoptar un plan que haya de reducirse a mera teoria; es necesario consultar la opinión de ciertas potencias, para lo cual no ha habido tiempo 57.

Gobierno y rey mantenían esta opinión "en la suposición siempre de la integridad de la monarquía en ambos hemisferios". Es decir, el principal problema que aducían era el imposible encaje jurídico de este proyecto en las bases constitucionales de la monarquía. Adoptarlo supondría modificarlas, algo para lo que -como señalaba el ministro- los diputados no tenian los poderes necesarios. Además, el consejo de Estado, a quien se le había solicitado un dictamen sobre el plan de monarquías americanas, aconsejaba a Fernando VII que bajo ningún concepto se separara del estricto cumplimiento de la Constitución.

56 La referencia a esta carta en José María Portillo Valdés, Fuero indio. Tlaxcala y la identidad territorial entre la monarquía imperial y la república nacional, 1787-1824, El Colegio de MéxicoInstituto Mora-CONACYT, México, 2014, p. 230. Parte del texto, casi íntegro, lo reproduce José Sánchez-Arcilla Bernal, "Un proyecto para la pacificación de la Nueva España (1821), en Recuerdos literarios en honor a un gran historiador de Castilla: Gonzalo Martinez Diez (1924-2015), Dykinson, 2016, notas 20, 21 y 22.

57 ACD. Serie General, leg. 22, no 19. Sin foliar. El borrador del plan le había sido remitido por la comisión en 25 de mayo de 1821 para que el gobierno informara de las ventajas o perjuicios que pudieran originarse de la adopción del mismo. El propio Ramos de Arizpe indicó posteriormente que había sido él el encargado de llevarlo al ministro para que realizara sus observaciones. Véase Idea general sobre la conducta politica de D. Miguel Ramos de Arizpe, op. cit., p. 18. Un resumen de las propuestas en A. Navas Sierra, Utopia y atopia de la Hispanidad, op. cit., p. 263. 
La declaración del gobierno debió suponer una gran frustración para los diputados americanos, que asistieron circunspectos a la total inhibición de la comisión de Ultramar en este asunto ${ }^{58}$. Aunque en privado ya habían reconocido que el principal obstáculo para la total adhesión al plan se encontraba en el propio texto constitucional: "Las mayores dificultades que [...] ofrece son las que en lo legal se encuentran para el establecimiento de congresos parciales, o sean secciones de él, no hallándose tan a las claras [en] la Constitución"59. A pesar de ello, antes de que el ministerio mostrara las dificultades para aprobar el plan americano, estos mantenian una total confianza en que el triunfo estaba asegurado. No fue así. Como es conocido, los americanos presentaron en solitario su proyecto a las Cortes en la sesión de 25 de junio de 1821, apenas cinco días antes de que se cerraran la legislatura. El encargado de exponer el plan en la cámara fue el diputado por Guadalajara, el canónigo José Miguel Ramírez. En su exposición, los americanos van a intentar superar el principal escollo -y el más problemático- que habian planteado el gobierno y el rey, a saber, el de la inconstitucionalidad de la propuesta.

En su discurso, el diputado Ramírez admitía que su plan contenía medidas que se salían del orden regular, pero defendia que este no transgredia la Carta Magna ni alteraba "los fundamentos del sistema". Es más, la proposición pretendia "asegurar la monarquía manteniendo la integridad de esta". Los americanos insistian en que la Constitución de 1812, tal y como estaba, no podía ponerse en práctica en sus países si no se tomaban "medidas nuevas y eficaces para que los tres poderes puedan obrar en su esfera con la energía y prontitud que exige la necesidad y conveniencia del Estado"60. Y añadía:

Supongamos por un momento puesto en práctica el plan que se propone: ¿pueden los americanos apetecer un sistema de gobierno más liberal, más bien constituido, más económico, más análogo a las ideas del siglo y al genio americano? Parece que no se puede perfeccionar más una Monarquía moderada 61 .

Los mexicanos eran conscientes del carácter infractor de su propuesta y por ello apelaban a la prioridad por conservar la unión y bienestar de la mayoría de la nación: "las leyes se han formado para la felicidad de los pueblos, y no estos para sacrificarse a las instituciones". Si se aplicaba el plan se evitarian muchos males, como que Nueva España sucumbiera a las veleidades del sistema republicano, en

58 El conde de Toreno, con gran empatía hacia los americanos, anunció en las Cortes que la comisión dejaba en manos del gobierno la resolución de las medidas para la pacificación de América: "En este conflicto, la comisión nada puede proponer a las Cortes; porque tocando al Gobierno decidir la cuestión de hecho, esto es, la de la conveniencia y necesidad de adoptar ciertos medios, no creyendo éste que sea llegado el momento, la comisión no puede hacer otra cosa que limitarse á excitar el celo de los ministros a fin de que aceleren tan deseado momento". $D S C, 24$ de junio de 1821, p. 2448. Como indicaría Lucas Alamán, los diputados eran conscientes de que el plan no saldría adelante sin el apoyo del gobierno, y a pesar de que al principio habian convenido en él, no ofreció pistas sobre los motivos particulares por los que finalmente el ministerio había suspendido su juicio en este asunto. Lucas Alamán, Historia de Méjico..., op. cit., t. V, p. 553.

59 Carta del diputado poblano transcrita en J. Sánchez-Arcilla Bernal, "Un proyecto para la pacificación de la Nueva España”, op. cit., p. 388, nota 21.

60 DSC, 25 de junio de 1821, p. 2472.

61 Ibid., p. 2475. 
clara alusión a su vecino del norte y al resto de soluciones políticas puestas en marcha en otros territorios hispanoamericanos ${ }^{62}$.

Ramírez insistia en que las medidas planteadas combinaban ambos elementos fundamentales, de un lado, la salvación de la patria y de otro, el sostenimiento de las bases de la Constitución, con cuyos principios se sentían identificados. Pero añadía:

es verdad que las medidas que proponemos no están marcadas en ella; pero ¿podrian acaso preverse, al tiempo de formar este inestimable Código, todos los casos y circunstancias en que podia hallarse la Nación?63

Para sustentar sus argumentos, Ramírez apelaba a que las Cortes y el gobierno, cuando lo habian considerado necesario, se habian separado de la literalidad de la Constitución para conservar la soberanía y salvar a la patria. Y ello lo reconocía como un "principio natural" encaminado a obtener el bien de la nación. Para ello exponía el ejemplo de la venta de las Floridas, el sistema de elección de los suplentes -no previsto en el texto constitucional- o incluso el alzamiento que habia devuelto la libertad a la nación. Y espetaba: “¿Cuántos artículos de la constitución no se hicieron a un lado para acelerar como convenía la instalación del actual Congreso?"

Para el mexicano, el plan que se debatía era el mejor posible, porque permitiria que se aplicara la norma constitucional en toda su extensión, de modo que los tres poderes -ejecutivo, legislativo y judicial- tendrian capacidad para obrar de manera pronta en los casos necesarios y así se evitaría la excesiva dilación que la distancia entre América y el centro del poder en la Península imprimía a los asuntos americanos. Así lo consideraba el diputado cuando afirmaba que las medidas que presentaban

en vez de contrariar los principios esenciales de la Constitución, no tienen otro objeto que remover los embarazos que impiden su establecimiento en América, y que dejando intactos los fundamentos del sistema, lo hagan efectivo en aquella gran parte de la monarquía64.

Esta división de los poderes del Estado en tres secciones americanas no les parecía a los diputados que resultara en ningún inconveniente para la organización interna de la monarquía. Si bien es cierto que en la Constitución gaditana no había quedado cerrada la estructura territorial del Estado, ni se preveía ningún mecanismo que evitara algún futuro efecto disgregador de la misma, Ramírez entendia que la propuesta mexicana perfeccionaba la monarquía

62 En este sentido apuntaba: "No es esta una mera teoría: a la vista del Congreso está el ejemplo del Canadá, que teniendo en su mano ligarse con los Estados Unidos, no lo ha intentado, porque ha juzgado mejor el gobierno de que ahora tratamos, aunque no lo posee con tanta perfección como aqui se propone". Ibidem.

63 Ibid., p. 2472.

64 Ibid., p. 2476. En su publicación Libraos de Ultramaria, Jeremy Bentham insistía en que la Constitución de 1812 no se podia aplicar a América. Entre otras cosas porque no podía ser enmendada hasta pasados ocho años. Miriam Williford, Jeremy Bentham on Spanish America. An Account of His Letters and Proposals to the New World, Louisiana State University Press, Baton Rouge and London, 1980, p. 47. También Ignacio Fernández Sarasola, "El debate doctrinal en torno a Cádiz", Revista española de la función consultiva, n 19, 2013, pp. 155-170. 
moderada y que de su ejecución resultaría "que ambas partes de la monarquía propenderán naturalmente a una eterna unión".

El punto fuerte de la argumentación de los americanos se basaba en el cumplimiento extensivo del artículo 13 de la Constitución, que hacía referencia a la felicidad de la nación como objeto primordial del gobierno. Esta lectura aislada y omnicomprensiva del precepto constitucional presentaba la felicidad de los pueblos y el bienestar de los ciudadanos como un valor superior del ordenamiento jurídico, por encima de cualquier otro contenido en la norma constitucional. Ello podía llevar a vaciar de contenido otros preceptos básicos de la Constitución, pero no era el momento de considerarlo, pues lo que les interesaba a los americanos era demostrar que su propuesta no podía ser calificada de inconstitucional. Preferian insistir en que una mirada excesivamente procedimentalista o rigorista del texto podría desvirtuar su esencia y acabar vulnerándolo por el lado de los valores superiores en él establecidos.

Sin embargo, eran conscientes de que sería preciso alguna pequeña modificación "salvando así las bases sustanciales de nuestro Código aún cuando para ello sea preciso tocar en algo su parte reglamentaria":

¿Podrá decirse contrariado el Código precioso de la libertad, si no siendo posible en el orden de la naturaleza salvar sus primeros elementos sin aventurar algo de lo reglamentario, nos decidimos a la conservación de los primeros? ¿Haremos por ventura, más mérito de las palabras que de las cosas, y despreciaremos los objetos más sublimes, los más grandes intereses, por respetar la exterioridad sola del lenguaje? Procediendo de tal modo ¿podremos tener la gloria de decir: ¿hemos defendido, hemos salvado las leyes fundamentales de la monarquía? [...] ¿qué dirá el mundo de nosotros, viéndonos sacrificar la esencia de la ley, su objeto y resultados benéficos, en obsequios de los accidentes, de la exterioridad y las palabras?65

Básicamente, lo que Ramírez estaba expresando ante los diputados era que no hacía falta reformar la Constitución, sino que sería suficiente con establecer la nueva organización político-territorial del Estado en un nivel normativo infraconstitucional, sin alterar el carácter de aquella. Por la vía del desarrollo legislativo -y en su caso, reglamentario- podian articularse formas alternativas de estructurar la monarquía que no vulneraran principios básicos como la unidad de la misma. A su parecer, quienes se empeñaban en la inconstitucionalidad del plan estaban atendiendo únicamente a cuestiones formales, accidentales, lo reducian todo a la exterioridad del lenguaje, incapaces de comprender que con estas medidas se protegían las leyes fundamentales de la monarquía.

En este sentido, según el planteamiento de los diputados americanos no era necesario operar reforma alguna en la letra de la Constitución, sino que bastaria con que el parlamento reinterpretase, a través de normas de inferior rango, el diseño institucional y territorial constitucionalmente consagrado. Se pretendia, pues, la metamorfosis de la Constitución sin alterar un ápice de su literalidad. Descartada la activación de los procedimientos reglados para el cambio formal, los representantes americanos propugnaban uno informal, esto es, la deliberada atribución de un nuevo significado o sentido a la Constitución sin modificar su expresión escrita. La propuesta americana se presentaba, en

${ }^{65} D S C, 25$ de junio de 1821 , p. 2476. 
suma, como una temprana manifestación -o, si se prefiere, de tentativa- de aquello que la doctrina alemana categorizaría unas décadas más tarde como mutación constitucional ${ }^{66}$.

Ya en el debate gaditano sobre el título $\mathrm{X}$, los diputados americanos no habian planteado límites materiales a las reformas. Más bien habian interpretado que cualquiera de las Cortes futuras, podría reformar el texto sin necesidad de convocar un poder constituyente constituido. Ello no suponía negar el poder constituyente, sino que, al estilo rousseauniano, dado que la nación se identificaba con las Cortes, cualquiera de ellas, no necesariamente unas especiales, podrian reformar en cualquier momento la norma fundamental67. Y aunque en este proyecto no plantearan de forma explícita una modificación del texto -más bien al contrario, la negaban constantemente conocedores de la dificultad de conseguir un consenso en este sentido- era claro que sustentaban un cambio en la concepción jurídica del territorio de la monarquía. Es decir, planteaban, sin nombrarlo, una federación.

Los diputados americanos esperaban que las medidas propuestas en las Cortes se discutieran en la siguiente legislatura extraordinaria que debia abrirse en el mes de septiembre de 1821. Algunos, como el poblano Ignacio de Mora, habian escrito a sus representados informándoles de que la ansiada autonomía estaba cada día más cerca. Según Mora, las medidas presentadas eran las únicas que podian cumplir con el doble objetivo de aplicar la Constitución en América y, al mismo tiempo, lograr su completa pacificación. Pero advertía: "que no habiendo tenido mas que primera lectura, deberá tratarse de él en las Cortes extraordinarias"68.

Pero el rey no estaba dispuesto a dar la partida por perdida, y sólo después de asegurarse que el plan americano no sería discutido, convocó las Cortes extraordinarias, in extremis, el 28 de junio.

\subsection{El "inevitable" final}

Desde finales de septiembre de 1821 se retomaron las sesiones de las Cortes en calidad de extraordinarias. El verano tocaba a su fin y la agitación social no paraba de crecer. El aumento de partidas realistas por todo el norte peninsular obedecía al triunfo absolutista de la Santa Alianza en Nápoles. La destitución de Riego provocó un incidente callejero entre los manifestantes en apoyo del militar y la milicia nacional. En la capital mexicana, abria sus sesiones la Junta Provisional Gubernativa que se iba a encargar de organizar el nuevo Estado diseñado en el Plan de Iguala. Por otro lado, las desalentadoras noticias de las derrotas españolas en América complicaban todavía más, si cabe, una solución pacífica e integradora para estos territorios en la monarquía.

\footnotetext{
${ }^{66}$ El concepto de mutación constitucional se debe a la Escuela de Derecho Público alemán. De entre sus miembros, quien más popularizó el término fue Georg Jellinek, Reforma y mutación de la Constitución, CEPC, Madrid, [1906] 1991.

67 J. Tajadura Tejada, "La defensa de la Constitución en los orígenes del constitucionalismo hispánico", op. cit., p. 538.

68 Carta enviada por Ignacio de Mora al ayuntamiento de Puebla de los Ángeles, 10 de julio de 1821. Archivo Histórico Municipal de Puebla, Actas de Cabildo, vol. 90 A, f. 473.
} 
Así las cosas, el 7 de noviembre de 1821 el Consejo de Estado evacuaba su informe sobre la cuestión americana. Este estuvo condicionado por la llegada de la noticia de la firma de los Tratados de Córdoba entre el capitán general O’Donojú y Agustín de Iturbide en agosto de ese año69. La consulta al Consejo se había restringido a los estrictos términos de pronunciarse sobre las "medidas relativas a la pacificación del continente". Después de exponer los antecedentes, las propuestas se reducían a la rigurosa "observancia de la Constitución sancionada para toda la monarquía española y por tanto la absoluta integridad que ella misma establece". De este modo, el Consejo reforzaba la unidad del imperio afirmando que no se consentiría la desmembración de parte alguna de la monarquía y, para conseguirlo, proponía el envío de fuerzas navales para afrontar la definitiva pacificación de los territorios.

Ante las presiones de los diputados americanos por conocer en qué estado se hallaba el expediente, finalmente el ministro de Ultramar, López Pelegrín, remitió a las Cortes el 17 de enero de 1822, la documentación que obraba en su poder respecto a la cuestión americana. En ella se incluía el acuerdo del Consejo de Estado de 7 de noviembre, la carta de O'Donojú donde daba razones de su conducta y la opinión del ministro al respecto de todo esto. En sesión secreta del día siguiente, se leyó íntegro el informe que había preparado el titular de Ultramar, dirigido a los secretarios de las Cortes. En él destaca la reiterada insistencia a negar que la crisis americana pudiera considerarse como un conflicto por la independencia. Para el ministro, los sucesos ocurridos desde hacía más de diez años "no tienen otro carácter que el de la divergencia de opiniones; llámense si se quiere disensiones de familia nacidas de justas o injustas quejas, y a lo más a que puede avanzarse es a graduarlos como una guerra civil"70. El tono del ministro era agraviante e hiriente, rozando lo humillante, en aras de demostrar que las Américas no estaban preparadas para gobernarse a sí mismas.

El informe -que copiaba casi a la letra la respuesta a la consulta del consejo de Estado- remataba con la propuesta de ocho medidas para conseguir la pacificación de América. Estas iniciaban con la suspensión de hostilidades por dos años para que las diputaciones y ayuntamientos manifestaran las quejas respecto a la administración o algunos artículos de la Constitución. De igual modo, y esto resulta de lo más interesante, López Pelegrín autorizaba que se tratara, con los diputados americanos, sobre la "suspensión en cuanto a Ultramar del artículo o artículos de la Constitución que consideren contiene obstáculo positivo a su prosperidad"71. De forma clara, el ministro recogía lo que había sido el centro neurálgico del debate americano: la imposibilidad de coexistencia entre la Constitución de 1812 y un estatus jurídico de autogobierno suficiente para los territorios americanos.

69 En los tratados se reconocía -entre otras cosas- la independencia de México bajo la forma de imperio constitucional moderado, llamando al trono en primer lugar a Fernando VII y, en su defecto, a los infantes Carlos María Isidro y Francisco de Paula.

70 ACD, Serie General, Leg. 22. No 19. Sin foliar.

71 De forma vaga e imprecisa y, probablemente, sin ningún tipo de sustento jurídico y legal, el ministro ofrecía la suspensión de artículos constitucionales para "contentar" a los americanos. La figura de la suspensión venía recogida en el artículo 308. Sin embargo, además de ser de carácter interino, se circunscribía únicamente a circunstancias extraordinarias (estado de excepción) y sólo al capítulo III del título V, a saber, el de las garantías procesales y la justicia criminal. El resto de medidas incluían ventajas de tipo comercial, reparto de baldíos y realengos a los indigenas y castas, y la suspensión de los decretos relativos a la reforma de regulares. Ibídem. 
Para analizar estos papeles se nombró una comisión de la que formaron parte tres diputados americanos cuyo dictamen se remitió pocos días después, devolviendo el expediente al ministro y concluyendo que las medidas del gobierno eran muy insuficientes y que este debía nombrar los comisionados que, en misión diplomática, viajaran a América ${ }^{72}$. Las últimas sesiones de las Cortes extraordinarias fueron muy acaloradas en lo que al tema americano se refiere. Mientras el consejo de Estado solicitaba el envío de fuerza armada, el gobierno seguía sus pasos en la propuesta de medidas de reconciliación que no integraban ningún atisbo de autogobierno para los americanos.

Las Cortes, atrapadas en la inacción, apostaban por una vía conciliatoria de envio de comisionados para entablar negociaciones. Por su parte, los diputados americanos exigían que los negociadores pudieran escuchar propuestas sobre el reconocimiento de la independencia, a lo que se negaban tanto el gobierno como la mayoría de los liberales peninsulares. El ministro López Pelegrín reiteraba en sede parlamentaria que las medidas anunciadas por el gobierno solo podian tener un sentido pacificador y que bajo ningún concepto podian entenderse como un paso hacia el posible reconocimiento de la independencia. El motivo estaba claro, eso sería "absolutamente contrario a un artículo expreso de la Constitución que todos hemos jurado, el cual no permite la desmembración de la monarquía"73. Una vez más, el texto constitucional suponía el principal escollo para la consecución de los planes americanos hacia el autogobierno. En su alegato insistía en que ni las Cortes ni el gobierno tenían poderes suficientes para autorizar la independencia, lo que dejaba esta decisión en las únicas manos posibles, las de Fernando VII.

Finalmente, la comisión de Ultramar dictaminó la nulidad de los Tratados de Córdoba firmados por O’Donojú e Iturbide y, en contra de la opinión de los americanos que la componían, abandonó el asunto de la pacificación de América a la suerte del resultado de las negociaciones de los comisionados que debian enviarse. Ya era tarde. México y Perú, los dos grandes ex virreinatos caminaban firmes hacia la consumación de sus propios Estados constitucionales e independientes. Ninguna de las corrientes del liberalismo peninsular defendió abiertamente el reconocimiento de la independencia americana, al menos de forma clara, en las Cortes. Y aunque algunos diputados convinieran con ello a título personal, no hubo consenso ni fuerza parlamentaria para imponerse al bloqueo de Fernando VII en este asunto ${ }^{74}$.

De este modo, se cerró la legislatura extraordinaria a finales de febrero de 1822. La mayoría de diputados americanos abandonaron sus escaños. No había sido posible la convergencia entre los principios liberales y constitucionales con el

72 En sesión secreta del día 18 de enero de 1822 se da cuenta de los miembros designados para esta comisión: Espiga, Toreno, Navarrete, Cuesta, Paul, Álvarez Guerra, Moscoso, Oliver y Murfi. DSC, 18 de enero de 1822, p. 2. El diputado Banqueri había solicitado que se imprimiese el dictamen con el informe del gobierno, a lo que no accedieron las Cortes. DSC de 24 de enero de 1822 , p. 1976.

73 DSC, 30 de enero de 1822, p. 2063.

74 El diputado Juan Antonio Yandiola recordaría con cierta nostalgia la oportunidad perdida con la negativa a aprobar el plan de Cortes que, en junio de 1821, hubiera supuesto el reconocimiento de la independencia americana integrada en la monarquía. $D S C, 13$ de febrero de 1822 , p. 2299. 
reconocimiento de la independencia. No lo había sido con una Constitución cuya rígida concepción de la soberanía impedía una solución federal que hubiera mantenido a los americanos en el marco territorial de la monarquía. Porque, como se ha visto, ninguna fracción del liberalismo peninsular estaba dispuesta a abrir el tortuoso procedimiento de la reforma constitucional.

\section{EPÍlOGO: ¿IMPIDIÓ LA CONSTITUCIÓN DE 1812 UNA SOLUCIÓN PARA AMÉRICA?}

La legislatura ordinaria de 1822 fue escenario de un frenesí político en el que las distintas facciones exacerbaron sus posiciones. Los sucesos de julio, el nombramiento del gabinete exaltado y la formación de la regencia de Urgell desestabilizaron el gobierno liberal y dieron alas a la propuesta de intervención armada de parte de las potencias europeas. El congreso de Verona fue, así, el lugar donde obligar a España a abandonar o modificar la Constitución. Aunque, en realidad, Francia nunca requirió formalmente esta reforma, sino que todo fueron insinuaciones vagas y comunicaciones no oficiales sobre el asunto.

En las Cortes del año 1823, fueron varias las ocasiones en las que los diputados discutieron sobre la posibilidad de modificar la Constitución para evitar la guerra. Los liberales más moderados consideraban que si España se avenía a aceptar las proposiciones de los gabinetes europeos, la intervención armada no se produciría. Estos se entregaron a la idea de que, aunque las potencias legitimistas no conviniesen con la Constitución de 1812, tampoco deseaban restaurar un gobierno absoluto incompatible con la civilización e ilustración de los tiempos. Por su parte, los serviles entendian que el congreso de Verona y su resolución no se hubieran producido si no era para restaurar la monarquía en toda su autoridad y poder.

Sin embargo, como insistiría Argüelles andando el tiempo, los que intentaban modificar anticipadamente la Constitución no eran un partido conocido dentro de la cámara representativa. Ni antes de las notas de los gabinetes europeos ni después, cuando el tema ya era tratado abiertamente en sede parlamentaria. Igualmente, el propio embajador británico confirmaba en su correspondencia al ministro Canning que los que deseaban modificar el texto constitucional no eran diputados ni tenían destinos de responsabilidad ${ }^{75}$.

En realidad, el problema central de todo el Trienio, tanto para Fernando VII como para los gabinetes legitimistas europeos, era la vigencia de la Constitución de 1812. La razón del recelo hacia la revolución española se encontraba en el mismo texto constitucional, considerado como una amenaza para la integridad de las monarquías europeas ${ }^{76}$. Una Constitución que ya no agradaba a casi nadie, pero que se había convertido en el símbolo de resistencia de la revolución y la lucha por la libertad. Por ello, plegarse a los designios europeos para su reforma

75 "De hecho, el proyecto de modificar la constitución sin aguardar al periodo que ella misma tenía designado, si es que existió alguna vez, no logró séquito en el público antes de las notas de Verona”. A. Argüelles, Reseña histórica, op. cit., 175 y ss.

76 Argüelles lo explicitaba en una de sus intervenciones: "Toda esta historia se reduce a que la Constitución española es el escándalo de la Europa y es una ley incompatible con la seguridad de los estados y particularmente de los Tronos". DSC, 4 de febrero de 1823. Citado en Juan Ferrando Badía, "La constitución española de 1812 y el congreso de Verona", Gades, n 16, 1987, pp. 57-90. También Canga Argüelles: "las pretensiones están reducidas a que mudemos la Constitución promulgada en Cádiz; quieren dos Asambleas, quieren dos Cámaras”. Ibídem. 
no era una opción contemplada por el liberalismo peninsular. Y en esa "heroica" resistencia, se llevaron por delante a los liberales americanos. La frustración con la que terminó la legislatura extraordinaria apenas dejó una exigua representación americana, pues tan solo los antillanos y filipinos permanecieron en las Cortes. Estos tuvieron que enfrentarse a la única solución que el liberalismo peninsular encontró para mantener unidos a sus territorios: la creación de un modelo organizativo particular para ellos ${ }^{77}$. Algo que se institucionalizaría con el siguiente texto constitucional de 1837.

En este sentido, al liberalismo peninsular le resultó tremendamente difícil conjugar la existencia de la Constitución con el deseo de mayor autogobierno de los americanos. Los diputados peninsulares no podían entender cómo los americanos no se conformaban con el regreso del sistema constitucional que, como bálsamo reparador, debia restañar las heridas y devolver todo al orden establecido. En realidad, no era la Constitución en sí misma la que suponía un escollo para los planes americanos, sino la concepción soberana que los diputados liberales le habían imprimido en su diseño territorial en Cádiz. Única e indivisible, la soberanía pertenecía en exclusiva a las Cortes de la nación. En contraposición, los americanos concibieron como soberanas también a las diputaciones provinciales, lo que suponia que este atributo correspondia de igual modo a los gobiernos de las provincias, permitiendo así la organización descentralizada y federal del territorio ${ }^{78}$.

Pero lo que no pudo ser en 1812 tampoco fue viable en 1821. La confianza bisoña que los liberales depositaron en Fernando VII, al principio sincera $\mathrm{y}$, después, forzada por las circunstancias, derivó en la excesiva rigidez por mantener intocable el texto constitucional. Las consecuencias que se pagaron por intentar constitucionalizar a un rey absoluto como Fernando VII fueron tremendamente altas. No sólo se perdió América, sino que arrastró en su caída al régimen liberal entero. Sorprende que el liberalismo español, ya en el exilio y mostrando cierta nostalgia - como ha indicado Gonzalo Butrón ${ }^{79}$ - de lo que habría podido ser y no fue, no hiciera mención a la cuestión americana como parte del elevado precio pagado. Tampoco los diputados americanos -que más adelante ocuparian cargos de responsabilidad en sus gobiernos independientes y relatarian en sus memorias su paso por las Cortes de Madrid-, refirieron nunca la problemática generada por su interpretación descentralizada de la Constitución de 1812 respecto a la rigidez de la misma. Pero, sin duda, las divergentes interpretaciones sobre el texto constitucional y su posibilidad de reformarlo o no, estuvieron en el centro de la problemática territorial americana del Trienio liberal.

Fecha de envío / Submission date: 12/02/2020

Fecha de aceptación / Acceptance date: 28/04/2020

77 La ley Gómez Becerra estableció un proyecto político-administrativo de la monarquía en el que se excluía a los territorios americanos que serían gobernados por unas leyes particulares. Agustín Sánchez Andrés, "La búsqueda de un nuevo modelo de relaciones con los territorios ultramarinos durante el Trienio Liberal", Revista de Indias, vol. LVII, n 210 (1997), p. 463.

78 Fue esta una opinión ya expuesta en los debates gaditanos sobre el título X de la Constitución. Al plantear que cualquiera de las Cortes, y no necesariamente las constituyentes, pudieran reformar la Constitución, abrian la puerta a la existencia de la pluralidad de soberanias.

79 Véase el texto de Gonzalo Butrón Prida en este mismo dossier. 